\title{
Effects of Self-regulatory Strategy on Prospective Science Teachers' Chemistry Self Efficacy According to Class Level and Gender
}

\author{
Hatice Güngör Seyhan \\ Correspondence: Hatice Güngör Seyhan, Faculty of Education, Cumhuriyet University, Sivas, Turkey
}

Received: November 25, 2015

Accepted: December 4, 2015 Online Published: December 29, 2015

doi:10.11114/jets.v4i3.1213

URL:http://dx.doi.org/10.11114/jets.v4i3.1213

\begin{abstract}
This study aimed at determining the self-regulatory strategies and the chemistry self-efficacies of a total of one hundred and eighty-nine prospective science teachers in a state university in Turkey while studying the chemistry lesson according to the class level and gender factors. An additional goal was to examine the relationship level between the self-regulatory strategies and their chemistry self-efficacies of prospective science teachers. In the study, "Self-Regulatory Strategies Scale" and "Chemistry Self-Efficacy Scale" were used. As a result of the study, it was observed that these strategies used by prospective science teachers while studying for chemistry lesson and their chemistry self-efficacies changed according to the class level and gender factors. It was observed also at the end of the study that the significant of the relationship between self-regulatory strategies and chemistry self-efficacy levels differed depending on the class level.
\end{abstract}

Keywords: chemistry self-efficacy, class level, gender, prospective science teacher, self-regulatory strategies

\section{Introduction}

One of the problems mostly encountered by the students while studying is that they are not aware what they are learning or doing while studying (Kadığlu, Uzuntiryaki \& ÇapaAydın, 2011). Students have many difficulties such as time management, choosing effective learning strategies, taking notes and preparing for the tests (Zimmerman, Bonner \& Kovach, 1996). Development of learning should include not only the improvement of content information but also the development of studying skills, social skills and desired motivational orientations in order to help students being independent, life-long learners (Kadıŏlu, Uzuntiryaki \& Çapa-Aydın, 2011). According to them, studies carried out in the recent years give priority to "how individuals learn" and "how individuals regulate themselves in order to learn", in more general terms, to self-regulation. Various researches include empirical findings regarding the relation between self-regulation strategies and academic success, motivational orientation and self-efficacy beliefs (Haşlaman \& Aşkar, 2007; Orhan, 2008; Pintrich \& De Groot, 1990; Yükseltürk \& Bulut, 2009; Zimmerman \& Martinez-Pons, 1990; Zusho, Pintrich, \& Coppalo, 2003). Therefore, self-regulation is one of the most important structures in education. It is considered that all students use self-regulatory strategies within limits. Therefore, it is not appropriate to mention the absence of self-regulation or students without self-regulation (Winne, 1997).

It has been determined that there is various definition of the "self-regulated learning" concept. According to Zimmerman, SRL is defined as "self-generated thoughts, feelings, and actions that are planned and cyclically adopted to the attainment of personal goals" (Zimmerman, 2000, p.14). Self-regulation is an important component of learning for college students (Pintrich, 1995). Self-regulated learning has been the focus of much attention during the last decade (Zimmerman \& Schunk, 1989; Pintrich, 1995; Garcia, 1996). According to Boekaerts (1999), SRL is viewed as a key to success in a career. According to a recent definition (Zeidner, Boekaerts \& Pintrich, 2000), self-regulation is conceived of as an overarching construct covering aspects such as self-regulated learning, the regulation of one's health and stress management, which in turn cover lower level activities such as strategy use, self-observation and automaticity. It has been defined as the ability to actively monitor and regulate one's learning via the use of a variety of cognitive, metacognitive, and behavioral strategies, including exerting effort, managing resources, organizing and processing information, and self-testing (Boekaerts 1999; Boekaerts \& Cascallar, 2006; Webster \& Hadwin, 2014; Zimmerman 2000; 2008).

Self-regulated learners possess the ability to evaluate their own progress in relation to the goals they have set and to adjust their subsequent behavior in the light of those self-evaluations (Olaussen \& Bråten, 1999; Purdie, Hattie, \& Douglas, 1996). It has been classified these strategies as self-evaluation, organizing and transforming, goal-setting and 
planning, help-seeking, keeping records and monitoring, environmental structuring, rehearsing and memorizing, seeking social assistance, and reviewing records (Zimmerman, 1990). According to Schloemer and Brenan (2006), there are the key elements of SRL; (a) goal setting, (b) self-monitoring and (c) modifying learning strategies. In addition, Puustinen and Pulkkinen (2001) are emphasize that among the different skills needed to become a self-regulated learner, various theorists have considered the strategies of self-evaluation and monitoring to be vital to success. According to Panadero and Romero (2014), these skills are needed for students to be able to judge their own work. These learners engage in productive self-regulated learning (SRL) by setting high-quality goals, selecting appropriate tactics to achieve those goals, monitoring progress and adapting as necessary (Winne \& Hadwin, 2008).

Social cognitive theories emphasize the importance of motivational beliefs such as self efficacy in students during periodical stages of self-regulation (Schunk\& Zimmerman, 1998). Through the self-regulatory learning, belief of students in their own capabilities is defined as self-efficacy belief (Zimmerman, Bandura \& Martinez-Pons, 1992) Those who have high self-efficacy in science tend to be interested in science and related courses and activities, they try very hard to succeed and they do not easily give up when they face a challenge (Andrew, 1998; Bandura, 1997; Britner \& Pajares, 2001; Lau \&Roeser, 2002). According to the findings of studies which examine students' self-efficacy in science, compared to such factors as race, gender or family environment, self-efficacy in science is a better determiner of the wish to deal with science and science-related activities and a better predictor of academic achievement (Lau \&Roeser, 2002; Lodewyk \& Winne, 2005; Pajares, 2002; Pintrich \& De Groot, 1990; Wolters \& Pintrich, 1998). Researchers of self-efficacy usually think that students' belief in their ability to succeed in science-related tasks, courses or activities or their sense of self-efficacy has a great effect in their selecting activities related to science, in the efforts they make to realize these activities, in their eventual success after their tenacity and experience (Bandura, 1997; Britner \& Pajares, 2001; Britner, 2008; Zeldin \& Pajares, 2000). This case also explains why students with similar abilities have different academic performances (Pajares, 1996). Moreover, it was also determined that self-efficacy is a better determiner for selecting science-related professions (Gwilliam \& Betz, 2001). Although self-efficacy has an important role in science education, it is also reported that there is an increase in the number of students who have no interest in science or belief in themselves when it comes to science (Pell \& Jarvis, 2001). Thus, it is important to find ways to increase students' self-efficacy. In addition to many quantitative studies that target determining the factors that affect prospective teachers' self efficacy beliefs, there are also qualitative studies (Büyükduman, 2006; Carrier, 2009; EkinciVural \& Hamurcu, 2008; Gibson \& Dembo, 1984; İşler, 2008; Ritter, Boone \& Rubba, 2001).

There are many definitions for chemistry self-efficacy in literature, which is defined as "a student's belief in his or her success in a college chemistry class" (Dalgety, Coll \& Jones, 2003). According to Çapa-Aydın and Uzuntiryaki (2009), chemistry self-efficacy is one's belief in his or her own ability to accomplish chemistry-related tasks. According to Summers (2009), chemistry self-efficacy is the belief to have the ability to act or realize the tasks related to chemistry theory and skills. Chemistry self-efficacy is accepted to be an important emotional part of chemistry learning. Therefore, self-efficacy plays an important role in enhancing students' motivation and especially as an in-class teaching methodology (Garcia, 2010). The first study on chemistry self-efficacy was done by Kerns (1981) in which he examined students' chemistry and mathematics self-efficacy. In later years, Boyd (1990) conducted a study, which examined students' chemistry self-efficacy and their anxiety.

When studies which examine chemistry self-efficacy and several factors affecting this self-efficacy are taken into consideration, it is seen that mostly there are studies on the general state of self-efficacy in students/prospective teachers or in existing teachers, on achievement in chemistry, on chemistry motivation, and on their relationship with self-regulatory learning strategies (Andrew 1998; Britner \& Pajares, 2001; Dalgety \& Coll, 2006; Kan \& Akbaş, 2006; Larose, Ratelle, Guay, Senécal, \& Harvey, 2006; Lent, Lopez, \& Bieschke, 1991; Quimby \& O’Brien, 2004; Scott \& Mallinckrodt, 2005; Smist, 1993; Zeldin \& Pajares, 2000). The concept of self-regulated learning has become increasingly important in higher education. Contrary to primary and secondary schooling, university education imposes distinctive demands on students, which requires them to be proactive and self-disciplined learners capable of controlling their own learning via self-monitoring and self-evaluation (Ning \& Downing, 2014).

\subsection{Aim of this Study}

Accordingly, in this study the levels of the self-regulatory strategies used by Turkish prospective science teachers while studying the chemistry lesson and the levels of their chemistry self-efficacy were determined. The specific problems of this study are as follows:

- How are the levels of the self-regulatory strategies used by Turkish prospective science teachers attending the same class between $1^{\text {st }}-4^{\text {th }}$ classes of university while studying for the chemistry lesson?

- How are the levels of the chemistry self-efficacy of Turkish prospective science teachers attending the same class between $1^{\text {st }}-4^{\text {th }}$ classes of university? 
- Are there significantly differences in the levels of the self-regulatory strategies used by Turkish prospective science teachers while studying for the chemistry lesson and the levels of their chemistry self-efficacy attending the same class between $1^{\text {st }}-4^{\text {th }}$ classes of university change according to gender?

- Are there significantly differences in the levels of the self-regulatory strategies used by Turkish prospective science teachers while studying for the chemistry lesson and the levels of their chemistry self-efficacy attending the same class between $1^{\text {st }}-4^{\text {th }}$ classes of university change according to the class level?

- Are there a significantly difference in the relationship level between the self-regulatory strategies and the chemistry self-efficacies of 189 Turkish prospective science teachers?

\section{Research Methodology}

\subsection{Research Design}

In this study, relational screening model, which aims at determining the existence or degree of a covariance between two or more variables, of the screening model which is one of the research approaches aiming at defining a situation that existed in the past or still exists as it was or it is. While using the relational screening model, correlation type way was adopted in relational analysis. In correlation type relation searching, whether the variables co-vary and if there are co-variations, how this happens are tried to be learned (Karasar, 2005).

\subsection{Respondents}

A total of one hundred and eighty-nine university students attending the Department of Science Education $\left(1^{\text {st }}, 2^{\text {nd }}\right.$, $3^{\text {rd }}$ and $4^{\text {th }}$ classes) of a university in Turkey who have taken General Chemistry course in university level participated in this study. Mean age was 20.6 years (range 18-22 years). Distributions of prospective teachers in the research group according to gender and class level are given in Table 1.

Table 1. Research group

\begin{tabular}{llllll}
\hline \multirow{2}{*}{ Class Level } & \multicolumn{2}{l}{ Male } & \multicolumn{2}{l}{ Female } & Total \\
\cline { 2 - 6 } & f & Frequence \% & F & Frequence \% & F \\
\hline Class 1 & 26 & $51.00 \%$ & 25 & $49.00 \%$ & 51 \\
Class 2 & 22 & $50.00 \%$ & 22 & $50.00 \%$ & 44 \\
Class 3 & 28 & $56.00 \%$ & 22 & $44.00 \%$ & 50 \\
Class 4 & 23 & $52.30 \%$ & 21 & $47.70 \%$ & 44 \\
\hline Total & 99 & $52.40 \%$ & 90 & $47.60 \%$ & 189 \\
\hline
\end{tabular}

It is seen that the prospective teachers in the research group have a balanced distribution in terms of gender (Male $=$ $52.40 \%$ and Female $=47.60 \%$ ) and class level.

\subsection{Instruments}

\subsubsection{Self-Regulatory Strategies Scale (SRSS)}

Cronbach's alpha internal reliability coefficient of eight-factor scale developed by Kadıoğlu, Uzuntiryaki and Çapa-Aydın (2011) was used to measure the self-regulatory strategies used by high school students while studying for chemistry lesson varied in the interval of .68-.82. As the original target group of the scale was high school students, this scale was applied for 192 undergraduate students who have taken general chemistry course prior to this study. As a result of confirmatory factor analysis, all relations of sub-scales with each other and with scale point were found to be meaningful. That the sub-scales of the scale indicated a high level relation in positive direction with scale point supported the structure validity of the scale in positive direction. Also, the fact that correlation values among the factors varied between .61 and .72 indicated that the factor structure of the scale was consistent. Cronbach's alpha value, which was estimated in order to examine the reliability of the scale, was in total .89 .

\subsubsection{Chemistry Self-Efficacy Scale (CSES)}

The original Chemistry Self-Efficacy Scale used of this study consisted of 17 positive items of 7-likert type (I am not sure at all-I am very sure) and has two sections (Dalgety, Coll \& Jones, 2003). The first section is about "chemistry knowledge" and it has two factors: Self Efficacy in Learning of Chemistry Theory - SLCT (3 items) and Self-Efficacy in Applying of Chemistry Theory - SACT (7 items). The other section is about "chemistry skills" and it has two factors: Self Efficacy in Learning Chemistry Skills - SLCS (3 items) and Self Efficacy in Applying Chemistry Skills - SACS (4 items). As a result of the factor analysis done in the chemistry self efficacy scale of the original questionnaire (CAEQ), it was seen that there is a high correlation between factor and that KMO value is .85 . Reliability analysis showed that the calculated total alpha value is .95 $(p<. \alpha)$.

In order for the scale to be used for prospective science teachers who have taken general chemistry course, adaptation to Turkish was done (Güngör Seyhan \& Eyceyurt Türk, 2015). To this end, the original scale, which consisted of 17 positive items, was translated into Turkish, and after the statistical analyses, it was seen that it gave reliable measuring 
results both at the factor level and at the scale level. The scale was applied to 496 university students for reliability and validity analyses. Alpha value calculated for CSES is .88 (17 items), alpha values for SLCT, SACT, SLCS, and SACS factors are $.50 ; .76 ; .55$ and .69 , respectively. According to these findings, it can be said that CSES has a high internal consistency and that it gives reliable measuring results. While the original scale is a 7-likert type, it was decided that it should be a 5-likert type (I am not sure at all - I am very sure) when adapting it to Turkish.

\subsection{Procedure}

Data obtained within the scope of the study were collected voluntarily in the course hours of prospective teachers by the researcher. The implementation of these scales took approximately 10 minutes.

\subsection{Data Analysis}

For the first and second research problems of the study, descriptive statistics of all answers were produced according to class levels in order to determine the general status of the self-regulatory strategies and their chemistry self-efficacies of prospective teachers while studying for the chemistry lesson. For the third research problem of the study, Mann-Whitney U test was applied in order to examine the significant of the difference between the answers given to SRSS and CSES items by female and male prospective teachers. If the dependent variable must be as least ordinal scaled, there are some references stating that Mann-Whitney U test can be applied (Fay \& Proschan, 2010; Freed, Hess \& Ryan, 2002; Winter \& Dodou, 2010). For the fourth research problem of the study, Kruskal-Wallis H test was used in order to examine the meaningfulness of the differences among the self-regulatory strategies and their chemistry self-efficacies of the prospective teachers according to all class levels in all item level. For this purpose, Chi-quare values are calculated for each item in order to compare the differences between the class levels. There are many references supporting this kind of calculation. (Dalgety, Coll \& Jones, 2003; Fay \& Proschan, 2010; Freed, Hess \& Ryan, 2002; Winter \& Dodou, 2010; http://www.ats.ucla.edu/stat/stata/whatstat/whatstat.htm). For the fifth research problem of the study, correlation matrix was arranged as the prospective teachers included in the research group were in different class levels. Multiple regression analysis was used to examine the predictive power and level of self-regulatory strategies of prospective teachers for their chemistry self-efficacies. These analyses were carried out via SPSS 15.0.

\section{Results}

\subsection{Descriptive Statistics of SRSS According to Class Levels}

In order to determine the self-regulatory strategies of prospective teachers, SRSS was used. For the scale consisted of eight sub-dimensions in total, which are motivation regulation, effort regulation, planning, attention focusing, summary strategy, highlighting strategy, using additional resources, and self-instruction, descriptive statistics of answers given to each item according to class levels are given in Table 2. 
Table 2. Descriptive statistics of SRSS item scores according to class levels

\begin{tabular}{|c|c|c|c|c|c|c|c|c|c|c|}
\hline & \multirow{2}{*}{\multicolumn{2}{|c|}{ Items }} & \multicolumn{2}{|c|}{ Class 1} & \multicolumn{2}{|c|}{ Class 2} & \multicolumn{2}{|c|}{ Class 3} & \multicolumn{2}{|c|}{ Class 4} \\
\hline & & & $\bar{X}$ & SD & $\overline{\bar{X}}$ & SD & $\overline{\bar{X}}$ & SD & $\overline{\bar{X}}$ & SD \\
\hline \multirow{4}{*}{ 도 } & Item 1 & $\begin{array}{l}\text { While studying for a topic, I give a break when I don't } \\
\text { understand something. }\end{array}$ & 4.14 & 1.37 & 4.64 & 1.16 & 4.56 & 1.23 & 4.61 & 1.40 \\
\hline & Item 2 & While studying, I quit if I am bored. & 4.18 & 1.41 & 4.64 & 1.18 & 3.80 & 1.46 & 4.52 & 1.28 \\
\hline & Item 3 & I quit studying if I don't understand the topic. & 3.67 & 1.42 & 3.82 & 1.33 & 3.50 & 1.52 & 4.16 & 1.54 \\
\hline & Item 4 & $\begin{array}{l}\text { On my desk, I only keep resources required for studying } \\
\text { (books, notebooks etc.) }\end{array}$ & 4.59 & 1.33 & 4.20 & 1.44 & 4.80 & 1.23 & 4.66 & 1.31 \\
\hline \multirow{5}{*}{$\underline{\underline{N}}$} & Item 5 & $\begin{array}{l}\text { I switch off the television in order to concentrate while } \\
\text { studying. }\end{array}$ & 4.80 & 1.44 & 4.91 & 1.48 & 5.04 & 1.37 & 4.59 & 1.60 \\
\hline & Item 6 & I try to remove the things, which distract me while studying. & 4.63 & 1.28 & 4.95 & 1.24 & 5.00 & 1.28 & 4.43 & 1.42 \\
\hline & Item 7 & $\begin{array}{l}\text { Before starting to study, I organize the environment in } \\
\text { which I will study. }\end{array}$ & 4.88 & 1.14 & 4.68 & 1.27 & 5.02 & 1.24 & 4.91 & 1.20 \\
\hline & Item 8 & I study in a quiet environment in order to concentrate. & 4.76 & 1.39 & 4.98 & 1.17 & 5.00 & 1.39 & 4.77 & 1.48 \\
\hline & Item 9 & I study the topic using different resources. & 3.78 & 1.27 & 3.57 & 1.23 & 3.76 & 1.35 & 4.32 & 1.25 \\
\hline \multirow[t]{4}{*}{$m$} & Item 10 & $\begin{array}{l}\text { While studying for a topic, I combine the information I } \\
\text { gather from different resources. }\end{array}$ & 4.47 & 1.35 & 4.11 & 1.28 & 3.86 & 1.58 & 4.73 & 1.04 \\
\hline & Item 11 & $\begin{array}{l}\text { While studying for a topic, I solve questions from test } \\
\text { books other than course books. }\end{array}$ & 3.57 & 1.40 & 3.77 & 1.54 & 3.50 & 1.61 & 4.55 & 1.47 \\
\hline & Item 12 & $\begin{array}{l}\text { While studying, I remind myself that the topic will be } \\
\text { necessary in my future life. }\end{array}$ & 3.57 & 1.32 & 3.27 & 1.42 & 3.38 & 1.40 & 3.98 & 1.41 \\
\hline & Item 13 & $\begin{array}{l}\text { I motive myself to study more thinking that I will get a high } \\
\text { grade. }\end{array}$ & 4.51 & 1.36 & 4.41 & 1.21 & 4.64 & 1.35 & 4.34 & 1.41 \\
\hline \multirow[t]{3}{*}{ 至 } & Item 14 & I motive myself to study in order to be loved by my teacher. & 3.71 & 1.66 & 3.25 & 1.54 & 2.74 & 1.58 & 3.09 & 1.64 \\
\hline & Item 15 & $\begin{array}{l}\text { I persuade myself that I need to study hard in order to learn } \\
\text { the topic. }\end{array}$ & 4.76 & 1.19 & 4.36 & 1.35 & 4.58 & 1.31 & 4.50 & 1.39 \\
\hline & Item 16 & $\begin{array}{l}\text { While studying, I remind myself how important getting a } \\
\text { good grade is. }\end{array}$ & 4.53 & 1.33 & 4.50 & 1.23 & 4.48 & 1.45 & 4.32 & 1.55 \\
\hline \multirow{4}{*}{ in } & Item 17 & While studying, I summarize the topic by drawing schemas. & 3.47 & 1.39 & 3.45 & 1.49 & 3.34 & 1.32 & 3.98 & 1.52 \\
\hline & Item 18 & While studying, I summarize using my own sentences. & 4.63 & 1.39 & 4.34 & 1.08 & 4.24 & 1.38 & 4.89 & 1.20 \\
\hline & Item 19 & I list the concepts, which I do not understand. & 4.14 & 1.31 & 3.82 & 1.48 & 4.08 & 1.47 & 4.07 & 1.35 \\
\hline & Item 20 & I explain myself the way I used while solving a question. & 4.31 & 1.45 & 4.43 & 1.37 & 4.34 & 1.33 & 4.57 & 1.15 \\
\hline \multirow{4}{*}{ b } & Item 21 & While studying for a topic, I explain the topic to myself. & 4.29 & 1.43 & 4.70 & 1.25 & 4.20 & 1.44 & 4.57 & 1.09 \\
\hline & Item 22 & $\begin{array}{l}\text { I ask myself questions in order to be sure that I understand } \\
\text { the topic I study. }\end{array}$ & 3.88 & 1.16 & 4.41 & 1.11 & 4.08 & 1.41 & 4.34 & 1.20 \\
\hline & Item 23 & I make a study plan before starting to study. & 3.67 & 1.32 & 3.14 & 1.19 & 3.80 & 1.29 & 3.84 & 1.49 \\
\hline & Item 24 & I list what I should do before starting to study. & 4.00 & 1.55 & 3.91 & 1.46 & 3.72 & 1.41 & 4.05 & 1.64 \\
\hline \multirow[t]{3}{*}{ 成 } & Item 25 & Before starting a study, I determine what I should learn. & 3.86 & 1.11 & 3.70 & 1.37 & 4.10 & 1.37 & 4.34 & 1.27 \\
\hline & Item 26 & $\begin{array}{l}\text { Before starting to study, I determine the way I will follow } \\
\text { during study. }\end{array}$ & 3.96 & 1.36 & 4.05 & 1.40 & 3.86 & 1.51 & 4.23 & 1.29 \\
\hline & Item 27 & $\begin{array}{l}\text { While studying I write down the definitions of important } \\
\text { concepts. }\end{array}$ & 4.14 & 1.44 & 4.55 & 1.23 & 4.98 & 1.25 & 4.93 & 1.25 \\
\hline \multirow[t]{2}{*}{$\infty$} & Item 28 & While studying for a topic, I underline the important points. & 4.94 & 1.19 & 5.05 & 1.03 & 5.04 & 1.03 & 5.18 & 0.99 \\
\hline & Item 29 & $\begin{array}{l}\text { While studying for a topic, I mark the important point with } \\
\text { color markers. }\end{array}$ & 4.25 & 1.56 & 4.75 & 1.37 & 4.64 & 1.48 & 4.93 & 1.07 \\
\hline
\end{tabular}

F1: Effort Regulation, F2: Attention Focusing, F3: Using Additional Resource, F4: Motivation Regulation, F5: Summary Strategy, F6: Self-Instruction, F7: Planning, F8: Highlighting Strategy.

When Table 2 is examined, it is seen that when answers of prospective teachers to the items in "effort regulation" dimension are examined, $3^{\text {rd }}$ class prospective teachers indicated lower participation compared to the prospective teachers in other class levels, the prospective teachers who indicated the highest effort were the $4^{\text {th }}$ class prospective teachers. However; when the items in "attention focusing" dimension are examined, it is seen that the $3^{\text {rd }}$ class prospective teachers have a very slightly participation compared to the prospective teachers in other classes. When answers of prospective teachers in "using additional resource" dimension are examined, it is seen that the 4 th class prospective teachers are differently higher than the other class levels. The situation is similar in terms of prospective teachers in other class levels. When "motivation regulation" dimension is examined, it is seen that the prospective teachers with the highest motivation were $1^{\text {st }}$ class prospective teachers. When "summary strategy" and "highlighting strategy" dimensions are examined, it is seen that the $4^{\text {th }}$ class prospective teachers particularly adopt the behaviors of diagram drawing, using their own sentences, underlining the important parts more than the prospective teachers in other class levels. In "planning" dimension, it is seen that when the class level is higher, planning behavior increases.

Kruskal-Wallis $\mathrm{H}$ test was used in order to examine the item level significant of differences among self-regulatory 
strategies of prospective teachers according to class levels and results are given in Table 3.

Table 3. Kruskal-Wallis H test results of SRSS according to class levels

\begin{tabular}{|c|c|c|c|c|c|c|}
\hline \multicolumn{3}{|r|}{ Hil } & \multirow{2}{*}{$\begin{array}{c}\text { Chi-square } \\
4.631\end{array}$} & \multirow{2}{*}{$\begin{array}{l}\mathbf{d f} \\
3\end{array}$} & \multirow{2}{*}{$\begin{array}{c}p \\
0.201\end{array}$} & \multirow{2}{*}{$\begin{array}{c}\text { Difference } \\
-\end{array}$} \\
\hline & Item 1 & $\begin{array}{l}\text { While studying for a topic, I give a break when I don't } \\
\text { understand something. }\end{array}$ & & & & \\
\hline I & Item 2 & While studying, I quit if I am bored. & 9.524 & 3 & 0.023 & $2-3,3-4$ \\
\hline & Item 3 & I quit studying if I don't understand the topic. & 5.427 & 3 & 0.143 & - \\
\hline \multirow{5}{*}{$\underline{\Sigma}$} & Item 4 & $\begin{array}{l}\text { On my desk, I only keep resources required for studying } \\
\text { (books, notebooks etc.) }\end{array}$ & 4.437 & 3 & 0.218 & - \\
\hline & Item 5 & $\begin{array}{l}\text { I switch off the television in order to concentrate while } \\
\text { studying. }\end{array}$ & 2.597 & 3 & 0.458 & - \\
\hline & Item 6 & I try to remove the things, which distract me while studying. & 6.997 & 3 & 0.072 & - \\
\hline & Item 7 & $\begin{array}{l}\text { Before starting to study, I organize the environment in which I } \\
\text { will study. }\end{array}$ & 2.431 & 3 & 0.488 & - \\
\hline & Item 8 & I study in a quiet environment in order to concentrate. & 1.287 & 3 & 0.732 & - \\
\hline \multirow{3}{*}{ M } & Item 9 & I study the topic using different resources. & 8.408 & 3 & 0.038 & - \\
\hline & Item 10 & $\begin{array}{l}\text { While studying for a topic, I combine the information I gather } \\
\text { from different resources. }\end{array}$ & 9.599 & 3 & 0.022 & $2-4,3-4$ \\
\hline & Item 11 & $\begin{array}{l}\text { While studying for a topic, I solve questions from test books } \\
\text { other than course books. }\end{array}$ & 14.469 & 3 & 0.002 & $1-4,2-4.3-4$ \\
\hline \multirow{5}{*}{ I } & Item 12 & $\begin{array}{l}\text { While studying, I remind myself that the topic will be necessary } \\
\text { in my future life. }\end{array}$ & 7.073 & 3 & 0.070 & - \\
\hline & Item 13 & $\begin{array}{l}\text { I motive myself to study more thinking that I will get a high } \\
\text { grade. }\end{array}$ & 1.777 & 3 & 0.620 & - \\
\hline & Item 14 & I motive myself to study in order to be loved by my teacher. & 9.152 & 3 & 0.027 & - \\
\hline & Item 15 & $\begin{array}{l}\text { I persuade myself that I need to study hard in order to learn the } \\
\text { topic. }\end{array}$ & 2.330 & 3 & 0.507 & - \\
\hline & Item 16 & $\begin{array}{l}\text { While studying, I remind myself how important getting a good } \\
\text { grade is. }\end{array}$ & 0.301 & 3 & 0.960 & - \\
\hline \multirow{4}{*}{ 经 } & Item 17 & While studying, I summarize the topic by drawing schemas. & 5.315 & 3 & 0.150 & - \\
\hline & Item 18 & While studying, I summarize using my own sentences. & 8.361 & 3 & 0.039 & - \\
\hline & Item 19 & I list the concepts, which I do not understand. & 1.297 & 3 & 0.730 & - \\
\hline & Item 20 & I explain myself the way I used while solving a question. & 0.799 & 3 & 0.850 & - \\
\hline \multirow{2}{*}{ to } & Item 21 & While studying for a topic, I explain the topic to myself. & 3.495 & 3 & 0.321 & - \\
\hline & Item 22 & $\begin{array}{l}\text { I ask myself questions in order to be sure that I understand the } \\
\text { topic I study. }\end{array}$ & 5.866 & 3 & 0.118 & - \\
\hline \multirow{4}{*}{ I } & Item 23 & I make a study plan before starting to study. & 6.750 & 3 & 0.080 & - \\
\hline & Item 24 & I list what I should do before starting to study. & 1.708 & 3 & 0.635 & - \\
\hline & Item 25 & Before starting a study, I determine what I should learn. & 8.157 & 3 & 0.043 & $1-4,2-4$ \\
\hline & Item 26 & $\begin{array}{l}\text { Before starting to study, I determine the way I will follow } \\
\text { during study. }\end{array}$ & 1.597 & 3 & 0.660 & - \\
\hline \multirow{3}{*}{ 我 } & Item 27 & $\begin{array}{l}\text { While studying I write down the definitions of important } \\
\text { concepts. }\end{array}$ & 13.585 & 3 & 0.004 & $1-3,1-4$ \\
\hline & Item 28 & While studying for a topic, I underline the important points. & 0.875 & 3 & 0.832 & - \\
\hline & Item 29 & $\begin{array}{l}\text { While studying for a topic, I mark the important point with } \\
\text { color markers. }\end{array}$ & 4.253 & 3 & 0.235 & - \\
\hline
\end{tabular}

F1: Effort Regulation, F2: Attention Focusing, F3: Using Additional Resource, F4: Motivation Regulation, F5: Summary Strategy, F6: Self-Instruction, F7: Planning, F8: Highlighting Strategy.

When Table 3 is examined, it is seen that the difference among the responses given by the prospective teachers to I2, I10, I11, I25 and I27 items are significantly according to the class level. Findings obtained by examining the contents of items given in Table 3 and difference groups and descriptive statistics given Table 2 together are as follows;

When the answers given to $\mathrm{I} 2$ item in the "effort regulation" dimension are examined, it is seen that $3^{\text {rd }}$ class prospective teachers are more inclined to quit studying when they are bored than $2^{\text {nd }}$ class and $4^{\text {th }}$ class prospective teachers. When the answers given to I10 and I11 items in the dimension of "using additional resource", it is seen that the $4^{\text {th }}$ class prospective teachers prefer combining information gathered from different resources in a significantly higher level that the $2^{\text {nd }}$ and $3^{\text {rd }}$ class prospective teachers. Also they are more meaningfully inclined to benefit from test books other than course books that all other class levels. When I25 item in "planning" dimension is examined, it is seen that the $4^{\text {th }}$ class prospective teachers prefer determining what should be learned before starting a study more than $1^{\text {st }}$ and $2^{\text {nd }}$ class prospective teachers. This situation indicates that the planning skills of $4^{\text {th }}$ class prospective teachers are higher than those of $1^{\text {st }}$ and $2^{\text {nd }}$ class prospective teachers. When "highlighting strategy" dimension is examined, it is seen that $3^{\text {rd }}$ and $4^{\text {th }}$ class prospective teachers prefer defining important concepts more than $1^{\text {st }}$ class prospective 
teachers do.

\subsection{Descriptive Statistics of CSES According to Class Levels}

For the CSES that consists of four sub-dimensions, namely, SLCT, SACT, SLCS and SACS, descriptive statistics of answers given to each item according to class level is given in Table 4.

Table 4. Descriptive statistics of CSES item scores according to class level

\begin{tabular}{|c|c|c|c|c|c|c|c|c|c|c|}
\hline \multirow{2}{*}{\multicolumn{2}{|c|}{ Items }} & & \multicolumn{2}{|c|}{ Class 1} & \multicolumn{2}{|c|}{ Class 2} & \multicolumn{2}{|c|}{ Class 3} & \multicolumn{2}{|c|}{ Class 4} \\
\hline & & & $\bar{X}$ & SD & $\bar{X}$ & SD & $\bar{X}$ & SD & $\bar{X}$ & SD \\
\hline \multirow{7}{*}{ 宨 } & Item 1 & $\begin{array}{l}\text { Applying a set of chemistry rules to different elements } \\
\text { of the periodic table }\end{array}$ & 2.33 & 0.91 & 3.77 & 0.68 & 3.68 & 0.77 & 4.30 & 0.67 \\
\hline & Item 2 & $\begin{array}{l}\text { Tutoring another student in a first year chemistry } \\
\text { course }\end{array}$ & 2.61 & 1.04 & 3.93 & 0.70 & 3.92 & 0.60 & 4.09 & 0.74 \\
\hline & Item 3 & & 3.29 & 0.97 & 4.02 & 0.70 & 4.18 & 0.60 & 4.11 & 0.69 \\
\hline & Item 4 & $\begin{array}{l}\text { Choosing an appropriate formula to solve a chemistry } \\
\text { problem }\end{array}$ & 3.94 & 0.73 & 4.11 & 0.65 & 4.04 & 0.70 & 4.14 & 0.67 \\
\hline & Item 5 & $\begin{array}{l}\text { After reading an article about a chemistry experiment, } \\
\text { you writing a summary of the main points }\end{array}$ & 2.71 & 0.88 & 3.98 & 0.70 & 4.16 & 0.62 & 3.86 & 0.46 \\
\hline & Item 6 & $\begin{array}{l}\text { dealing with } \\
\text { ting a }\end{array}$ & 2.61 & 0.83 & 3.61 & 0.72 & 4.06 & 0.74 & 3.80 & 0.59 \\
\hline & Item 7 & $\begin{array}{l}\text { After } \\
\text { chem } \\
\text { perso }\end{array}$ & 2.31 & 0.84 & 4.14 & 0.77 & 4.10 & 0.65 & 3.82 & 0.50 \\
\hline \multirow{3}{*}{ 它 } & & & 2.45 & 0.88 & 4.11 & 0.58 & 3.98 & 0.71 & 4.11 & 0.69 \\
\hline & Item 9 & Learning chemistry theory & 3.67 & 0.52 & 4.11 & 0.72 & 4.12 & 0.52 & 3.89 & 0.58 \\
\hline & Item 10 & 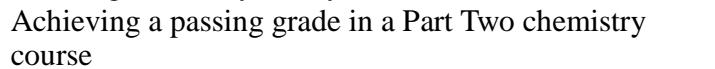 & 3.57 & 0.57 & 3.93 & 0.73 & 4.16 & 0.58 & 4.34 & 0.61 \\
\hline \multirow{4}{*}{$\sum_{\infty}^{\infty}$} & Item 11 & aninoful guestion that co & 3.04 & 0.80 & 3.64 & 0.78 & 3.86 & 0.76 & 3.66 & 0.48 \\
\hline & Item 12 & $\begin{array}{l}\text { Know } \\
\text { chemi }\end{array}$ & 3.71 & 0.58 & 4.27 & 0.69 & 4.08 & 0.63 & 4.18 & 0.72 \\
\hline & Item 13 & $\begin{array}{l}\text { Writing up the experimental procedures in a laboratory } \\
\text { report }\end{array}$ & 3.20 & 0.75 & 3.95 & 0.57 & 4.16 & 0.65 & 4.30 & 0.73 \\
\hline & Item 14 & Writing up the results section in a laboratory report & 2.16 & 0.90 & 4.18 & 0.66 & 4.10 & 0.51 & 3.75 & 0.53 \\
\hline \multirow{3}{*}{ 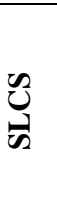 } & Item 15 & $\begin{array}{l}\text { Ensuring that data obtained from an experiment is } \\
\text { accurate }\end{array}$ & 3.02 & 0.86 & 3.57 & 0.90 & 3.72 & 0.67 & 4.02 & 0.63 \\
\hline & Item 16 & $\begin{array}{l}\text { Determining the appropriate units for a value } \\
\text { determined using a Formula }\end{array}$ & 3.53 & 0.64 & 4.02 & 0.63 & 3.78 & 0.71 & 3.86 & 0.46 \\
\hline & Item 17 & $\begin{array}{l}\text { Applying theory learning in a lecture for a laboratory } \\
\text { experiment }\end{array}$ & 3.71 & 0.54 & 3.86 & 0.67 & 3.90 & 0.65 & 3.82 & 0.50 \\
\hline
\end{tabular}

SACT: Self-Efficacy in Applying of Chemistry Theory, SLCT: Self Efficacy in Learning of Chemistry Theory, SACS: Self Efficacy in Applying Chemistry Skills, SLCS: Self Efficacy in Learning Chemistry Skills

When Table 4 is examined, the self-efficacy of the $1^{\text {st }}$ class prospective teachers regarding learning the theory of chemistry and particularly for the sub self-efficacy for implementing the chemistry theory is quite low compared to the other class levels. It was determined in the SACT sub self-efficacy of CSES that for item "after listening to a public lecture regarding some chemistry topic, explaining its main ideas to another person", especially $2^{\text {nd }}$ and $3^{\text {rd }}$ class prospective teachers feel quite confident. Again in the same sub self-efficacy, for item "applying a set of chemistry rules to different elements of the periodic table", $1^{\text {st }}$ class prospective teachers don't feel any self-efficacy compared to the members of other class levels. In SLCT sub self-efficacy of CSES, for self-efficacy regarding the learning the theory of a lesson which includes basic knowledge and acquirements about the subject of "chemical hazards"; it was observed that $1^{\text {st }}$ class prospective teachers don't feel self-efficacy. When the table is examined for the responses given by prospective teachers to the item "writing up the results section in a laboratory report" in implementing chemistry skills self-efficacy, it was observed that the $1^{\text {st }}$ class prospective teachers felt self-efficacy in a very low level compared to the prospective teachers in other class levels.

In order to examine the significantly of the difference between prospective teachers' reaction to items of CSES according to class level, Kruskal-Wallis $\mathrm{H}$ test results are given in Table 5. 
Table 5. Kruskal-Wallis H test results of CSES according to class level

\begin{tabular}{|c|c|c|c|c|c|c|}
\hline & Items & & Chi-square & Df & $p$ & Difference \\
\hline \multirow{7}{*}{ 点 } & Item 1 & $\begin{array}{l}\text { Applying a set of chemistry rules to different elements of the } \\
\text { periodic table }\end{array}$ & 86.306 & 3 & 0.000 & $\begin{array}{l}1-2,1-3,1-4,2-4, \\
3-4\end{array}$ \\
\hline & Item 2 & Tutoring another student in a first year chemistry course & 61.179 & 3 & 0.000 & $1-2,1-3,1-4$ \\
\hline & Item 3 & $\begin{array}{l}\text { Explaining something that you learning in this chemistry } \\
\text { course to another person }\end{array}$ & 32.745 & 3 & 0.000 & $1-2,1-3,1-4$ \\
\hline & Item 4 & Choosing an appropriate formula to solve a chemistry problem & 1.818 & 3 & 0.611 & - \\
\hline & Item 5 & $\begin{array}{l}\text { After reading an article about a chemistry experiment, you } \\
\text { writing a summary of the main points }\end{array}$ & 73.761 & 3 & 0.000 & $3-4$ \\
\hline & Item 6 & $\begin{array}{l}\text { After watching a television documentary dealing with some } \\
\text { aspect of chemistry experiment, writing a summary of its main } \\
\text { points }\end{array}$ & 69.788 & 3 & 0.000 & $2-3$ \\
\hline & Item 7 & $\begin{array}{l}\text { After listening to a public lecture regarding some chemistry } \\
\text { topic, explaining its main ideas to another person }\end{array}$ & 96.378 & 3 & 0.000 & $2-4,3-4$ \\
\hline \multirow{3}{*}{ 它 } & Item 8 & Achieving a passing grade in a chemical hazards course & 85.034 & 3 & 0.000 & $1-2,1-3,1-4$ \\
\hline & Item 9 & Learning chemistry theory & 17.616 & 3 & 0.001 & $1-2,1-3,1-4,3-4$ \\
\hline & Item 10 & Achieving a passing grade in a Part Two chemistry course & 33.623 & 3 & 0.000 & $1-2,1-3,1-4,2-4$ \\
\hline \multirow{4}{*}{$\sum_{\infty}^{\infty}$} & Item 11 & $\begin{array}{l}\text { Proposing a meaningful question that could be answered } \\
\text { experimentally }\end{array}$ & 26.456 & 3 & 0.000 & $1-2,1-3,1-4$ \\
\hline & Item 12 & $\begin{array}{l}\text { Knowing how to convert the data obtained in a chemistry } \\
\text { experiment to get a result }\end{array}$ & 19.038 & 3 & 0.000 & $1-2,1-3,1-4$ \\
\hline & Item 13 & Writing up the experimental procedures in a laboratory report & 51.146 & 3 & 0.000 & $1-2,1-3,1-4,2-4$ \\
\hline & Item 14 & Writing up the results section in a laboratory report & 107.11 & 3 & 0.000 & $\begin{array}{l}1-2,1-3,1-4,2-4, \\
3-4\end{array}$ \\
\hline \multirow{3}{*}{$\underbrace{\infty}$} & Item 15 & Ensuring that data obtained from an experiment is accurate & 32.657 & 3 & 0.000 & $\begin{array}{l}1-2,1-3,1-4,2-4 \\
3-4\end{array}$ \\
\hline & Item 16 & $\begin{array}{l}\text { Determining the appropriate units for a value determined } \\
\text { using a Formula }\end{array}$ & 12.557 & 3 & 0.006 & $1-2,1-3,1-4$ \\
\hline & Item 17 & $\begin{array}{l}\text { Applying theory learning in a lecture for a laboratory } \\
\text { experiment }\end{array}$ & 2.173 & 3 & 0.537 & - \\
\hline
\end{tabular}

When Table 5 was examined, it was seen that there is a significantly difference in the answers of prospective teachers from different class levels for all items except I4 and I17 items $(p<. \alpha)$. Kruskal-Wallis $\mathrm{H}$ test was done in order to determine at what class level the different occurs, and difference groups were determined as a result of this test. When Table 4 and Table 5 are examined together, the findings are as follows:

It was seen that prospective teachers in the $1^{\text {st }}$ class (freshman) have a significantly lower self efficacy compared to those in the $2^{\text {nd }}$ (sophomore), $3^{\text {st }}$ (junior) and $4^{\text {th }}$ (senior) classes in all items of CSES except of I4 item (GPA [freshman]: 3.94; [sophomore]: 4.11; [junior]: 4.04; [senior]: 4.14), I5 item (GPA [freshman]: 2.71; [sophomore]: 3.98; [junior]: 4.16; [senior]: 3.86), I6 item (GPA [freshman]: 2.61; [sophomore]: 3.61; [junior]: 4.06; [senior]: 3.80$)$, I7 item (GPA [freshman]: 2.31; [sophomore]: 4.14; [junior]: 4.10; [senior]: 3.82) and I17 item (GPA [freshman]: 3.71; [sophomore]: 3.86; [junior]: 3.90; [senior]: 3.82). It was seen that sophomores have a significantly lower self-efficacy at I6 item of CSES compared to juniors: (GPA [sophomore]: 3.61; [junior]: 4.06). No significantly difference could be observed for this item at other class levels. It was observed that sophomore prospective teachers have a significantly lower self efficacy compared to senior prospective teachers at I1 item of CSES (GPA [sophomore]: 3.77; [senior]: 4.30 ), I10 item (GPA [sophomore]: 3.93; [senior]: 4.34), I13 item (GPA [sophomore]: 3.95; [senior]: 4.30) and I15 item (GPA [sophomore]: 3.57 ; [senior]: 4.02).

\subsection{Descriptive Statistics of SRSS According to Gender}

Within the scope of the study, whether self-regulatory strategies of prospective science teachers in different class levels vary depending on the gender is among the examined sub-problems. With this purpose, descriptive statistics regarding the answers given to the items according to gender are given in Table 6. 
Table 6. Descriptive statistics of SRSS item scores according to gender

\begin{tabular}{|c|c|c|c|c|c|c|c|c|c|c|c|}
\hline \multirow{2}{*}{\multicolumn{2}{|c|}{ Items }} & & \multirow{2}{*}{ Gender } & \multicolumn{2}{|c|}{ Class 1} & \multicolumn{2}{|c|}{ Class 2} & \multicolumn{2}{|c|}{ Class 3} & \multicolumn{2}{|c|}{ Class 4} \\
\hline & & & & $\bar{X}$ & SD & $\bar{X}$ & SD & $\overline{\bar{X}}$ & SD & $\bar{X}$ & SD \\
\hline \multirow{6}{*}{ 压 } & \multirow{2}{*}{ Item 1} & \multirow{2}{*}{$\begin{array}{l}\text { While studying for a topic, I give a break when } \\
\text { I don't understand something. }\end{array}$} & Male & 4.15 & 1.62 & 4.82 & 1.05 & 4.39 & 1.23 & 5.04 & 1.33 \\
\hline & & & Female & 4.12 & 1.09 & 4.45 & 1.26 & 4.77 & 1.23 & 4.14 & 1.35 \\
\hline & \multirow{2}{*}{ Item 2} & \multirow{2}{*}{ While studying, I quit if I am bored. } & Male & 4.12 & 1.56 & 4.59 & 1.22 & 4.04 & 1.37 & 5.17 & 0.89 \\
\hline & & & Female & 4.24 & 1.27 & 4.68 & 1.17 & 3.50 & 1.54 & 3.81 & 1.29 \\
\hline & \multirow{2}{*}{ Item 3} & \multirow{2}{*}{ I quit studying if I don't understand the topic. } & Male & 3.38 & 1.58 & 3.95 & 1.33 & 3.68 & 1.59 & 4.91 & 1.31 \\
\hline & & & Female & 3.96 & 1.21 & 3.68 & 1.36 & 3.27 & 1.42 & 3.33 & 1.35 \\
\hline & & On my desk, I only keep resources required for & Male & 4.77 & 1.42 & 3.86 & 1.58 & 4.75 & 1.17 & 4.48 & 1.44 \\
\hline & $11 e m 4$ & study & Female & 4.40 & 1.22 & 4.55 & 1.22 & 4.86 & 1.32 & 4.86 & 1.15 \\
\hline & & I switch off the television in order to & Male & 5.54 & 0.90 & 4.73 & 1.45 & 4.93 & 1.51 & 4.52 & 1.83 \\
\hline & $\mathrm{em} 5$ & & Female & 4.04 & 1.51 & 5.09 & 1.51 & 5.18 & 1.18 & 4.67 & 1.35 \\
\hline $\mathrm{N}$ & Item 6 & I try to remove the things, which distract me & Male & 4.92 & 1.13 & 4.73 & 1.24 & 4.93 & 1.36 & 4.43 & 1.56 \\
\hline I & IIemin 0 & while s & Female & 4.32 & 1.38 & 5.18 & 1.22 & 5.09 & 1.19 & 4.43 & 1.29 \\
\hline & & Before starting to study, I organize the & Male & 5.23 & 1.03 & 4.41 & 1.37 & 5.00 & 1.31 & 5.04 & 1.02 \\
\hline & Item $/$ & envir & Female & 4.52 & 1.16 & 4.95 & 1.13 & 5.05 & 1.17 & 4.76 & 1.37 \\
\hline & & et environment in order to & Male & 5.15 & 1.32 & 4.77 & 1.31 & 5.04 & 1.29 & 4.57 & 1.59 \\
\hline & m 8 & & Female & 4.36 & 1.38 & 5.18 & 1.01 & 4.95 & 1.53 & 5.00 & 1.34 \\
\hline & & & Male & 4.12 & 1.56 & 3.41 & 1.18 & 3.50 & 1.20 & 4.13 & 1.36 \\
\hline & Item 9 & I stu & Female & 3.44 & 0.77 & 3.73 & 1.28 & 4.09 & 1.48 & 4.52 & 1.12 \\
\hline & & While studying for a topic, I combine the & Male & 4.85 & 1.19 & 3.86 & 1.28 & 3.57 & 1.55 & 4.61 & 1.20 \\
\hline & $m 10$ & infor & Female & 4.08 & 1.41 & 4.36 & 1.26 & 4.23 & 1.57 & 4.86 & 0.85 \\
\hline & & While st & Male & 3.77 & 1.56 & 4.09 & 1.60 & 3.57 & 1.73 & 4.61 & 1.34 \\
\hline & & from te & & 3.36 & 1.22 & 3.45 & 1.44 & 3.41 & 1.47 & 4.48 & 1.63 \\
\hline & & While & Male & 3.73 & 1.46 & 2.95 & 1.43 & 3.07 & 1.39 & 3.61 & 1.50 \\
\hline & $\mathrm{m} 12$ & will & & 3.40 & 1.15 & 3.59 & 1.37 & 3.77 & 1.34 & 4.38 & 1.20 \\
\hline & & I motive & & 4.92 & 1.38 & 4.41 & 1.05 & 4.14 & 1.48 & 4.17 & 1.64 \\
\hline & & will get a high grade. & Female & 4.08 & 1.22 & 4.41 & 1.37 & 5.27 & 0.83 & 4.52 & 1.12 \\
\hline & & I motive myself to study in order to be loved by & Male & 4.19 & 1.72 & 2.95 & 1.59 & 2.64 & 1.45 & 2.87 & 1.55 \\
\hline 工 & Item 14 & & & 3.20 & 1.47 & 3.55 & 1.47 & 2.86 & 1.75 & 3.33 & 1.74 \\
\hline & & I per & & 5.12 & 1.07 & 3.95 & 1.33 & 4.18 & 1.33 & 4.43 & 1.50 \\
\hline & & order to le & Female & 4.40 & 1.22 & 4.77 & 1.27 & 5.09 & 1.11 & 4.57 & 1.29 \\
\hline & & While stud & Male & 4.85 & 1.26 & 4.09 & 1.23 & 4.18 & 1.49 & 4.30 & 1.64 \\
\hline & & gettil & Fem & 4.20 & 1.35 & 4.91 & 1.11 & 4.86 & 1.32 & 4.33 & 1.49 \\
\hline & & While & & 3.62 & 1.44 & 3.14 & 1.36 & 3.32 & 1.36 & 3.65 & 1.67 \\
\hline & $\mathrm{m} 17$ & & & 3.32 & 1.35 & 3.77 & 1.57 & 3.36 & 1.29 & 4.33 & 1.28 \\
\hline$n$ & & While & Male & 5.00 & 1.36 & 4.23 & 1.15 & 4.39 & 1.23 & 5.17 & 1.19 \\
\hline 工贸 & & & Female & 4.24 & 1.33 & 4.45 & 1.01 & 4.05 & 1.56 & 4.57 & 1.16 \\
\hline & & & & 4.69 & 1.09 & 3.45 & 1.41 & 3.75 & 1.46 & 4.22 & 1.44 \\
\hline & m 19 & 1 list the concepts, which 1 do not understand. & & 3.56 & 1.29 & 4.18 & 1.50 & 4.50 & 1.41 & 3.90 & 1.26 \\
\hline & & I explain myself the way I used while solving a & Male & 4.62 & 1.60 & 4.23 & 1.19 & 4.11 & 1.31 & 4.65 & 1.27 \\
\hline & & question. & Female & 4.00 & 1.22 & 4.64 & 1.53 & 4.64 & 1.33 & 4.48 & 1.03 \\
\hline & & While studying for a topic, I explain the topic to & Male & 4.54 & 1.58 & 4.18 & 1.30 & 4.14 & 1.46 & 4.91 & 0.90 \\
\hline 国 & Item 21 & & & 4.04 & 1.24 & 5.23 & 0.97 & 4.27 & 1.45 & 4.19 & 1.17 \\
\hline & & I ask & Male & 4.19 & 1.23 & 4.05 & 1.09 & 3.68 & 1.47 & 4.43 & 1.38 \\
\hline & & & Female & 3.56 & 1.00 & 4.77 & 1.02 & 4.59 & 1.18 & 4.24 & 1.00 \\
\hline & & & Male & 4.00 & 1.47 & 3.18 & 1.40 & 3.68 & 1.47 & 3.87 & 1.46 \\
\hline & & & Female & 3.32 & 1.07 & 3.09 & 0.97 & 3.95 & 1.05 & 3.81 & 1.57 \\
\hline & & & Male & 4.42 & 1.39 & 3.77 & 1.38 & 3.57 & 1.50 & 3.83 & 1.72 \\
\hline & & & Female & 3.56 & 1.61 & 4.05 & 1.56 & 3.91 & 1.31 & 4.29 & 1.55 \\
\hline & & Before starting a study, I determine what I & Male & 4.23 & 1.14 & 3.32 & 1.39 & 3.93 & 1.39 & 4.22 & 1.41 \\
\hline & & shoulc & Female & 3.48 & 0.96 & 4.09 & 1.27 & 4.32 & 1.36 & 4.48 & 1.12 \\
\hline & & tudy, I determine the way I & Male & 4.27 & 1.34 & 4.00 & 1.48 & 3.50 & 1.53 & 4.04 & 1.33 \\
\hline & $\mathrm{m} \angle 0$ & will follow during study. & Female & 3.64 & 1.32 & 4.09 & 1.34 & 4.32 & 1.39 & 4.43 & 1.25 \\
\hline & & While studying I write down the definitions of & Male & 4.42 & 1.60 & 4.36 & 1.33 & 4.89 & 1.37 & 4.91 & 1.47 \\
\hline & & & Female & 3.84 & 1.21 & 4.73 & 1.12 & 5.09 & 1.11 & 4.95 & 0.97 \\
\hline & & dying for a topic, I underline the & & 5.00 & 1.39 & 5.09 & 1.06 & 4.86 & 1.04 & 5.43 & 0.73 \\
\hline 望 & Item 28 & & Female & 4.88 & 0.97 & 5.00 & 1.02 & 5.27 & 0.98 & 4.90 & 1.18 \\
\hline & & While studying for a & Male & 4.15 & 1.83 & 4.82 & 1.22 & 4.61 & 1.47 & 5.17 & 0.89 \\
\hline & & point with color markers. & Female & 4.36 & 1.25 & 4.68 & 1.52 & 4.68 & 1.52 & 4.67 & 1.20 \\
\hline
\end{tabular}

When Table 6 is examined, it is seen that there are differences between the answers given to the same items by male and female prospective teachers in the same class level. In order to examine the meaningfulness of the difference between 
the answers given to SRSS items by male and female prospective teachers, Mann-Whitney U test was carried out and the related results are indicated in Table 7 .

Table 7. Mann-Whitney U test results of SRSS according to gender in class levels

\begin{tabular}{|c|c|c|c|c|c|c|c|c|c|c|c|c|}
\hline \multirow{2}{*}{ Items } & \multicolumn{3}{|c|}{ Class 1} & \multicolumn{3}{|c|}{ Class 2} & \multicolumn{3}{|c|}{ Class 3} & \multicolumn{3}{|c|}{ Class 4} \\
\hline & $\mathbf{U}$ & $\mathbf{Z}$ & $\mathbf{P}$ & $\mathbf{U}$ & $\mathbf{Z}$ & $\mathbf{P}$ & $\mathbf{U}$ & $\mathbf{Z}$ & p & $\mathbf{U}$ & $\mathbf{Z}$ & $\mathbf{P}$ \\
\hline Item 1 & 317.00 & -0.16 & 0.88 & 202.50 & -0.97 & 0.33 & 254.50 & -1.08 & 0.28 & 144.00 & -2.37 & 0.02 \\
\hline Item 2 & 314.50 & -0.20 & 0.84 & 234.50 & -0.18 & 0.86 & 242.00 & -1.32 & 0.19 & 98.50 & -3.46 & 0.00 \\
\hline Item 3 & 244.00 & -1.56 & 0.12 & 200.50 & -1.01 & 0.31 & 259.00 & -0.98 & 0.33 & 92.00 & -3.59 & 0.00 \\
\hline Item 4 & 260.00 & -1.27 & 0.21 & 185.00 & -1.40 & 0.16 & 283.00 & -0.51 & 0.61 & 208.50 & -0.80 & 0.42 \\
\hline Item 5 & 137.50 & -3.78 & 0.00 & 198.50 & -1.10 & 0.27 & 287.00 & -0.46 & 0.65 & 231.50 & -0.25 & 0.81 \\
\hline Item 6 & 240.00 & -1.67 & 0.10 & 178.00 & -1.59 & 0.11 & 288.50 & -0.41 & 0.68 & 228.00 & -0.33 & 0.74 \\
\hline Item 7 & 199.00 & -2.49 & 0.01 & 187.00 & -1.34 & 0.18 & 307.50 & -0.01 & 0.99 & 221.50 & -0.50 & 0.62 \\
\hline Item 8 & 203.50 & -2.40 & 0.02 & 202.50 & -0.99 & 0.33 & 305.50 & -0.05 & 0.96 & 205.50 & -0.89 & 0.37 \\
\hline Item 9 & 193.00 & -2.58 & 0.01 & 213.50 & -0.69 & 0.49 & 243.00 & -1.30 & 0.19 & 198.50 & -1.04 & 0.30 \\
\hline Item 10 & 218.00 & -2.07 & 0.04 & 186.00 & -1.35 & 0.18 & 236.00 & -1.44 & 0.15 & 224.50 & -0.42 & 0.67 \\
\hline Item 11 & 260.50 & -1.24 & 0.21 & 174.50 & -1.61 & 0.11 & 293.50 & -0.29 & 0.77 & 240.50 & -0.02 & 0.98 \\
\hline Item 12 & 282.00 & -0.84 & 0.40 & 175.50 & -1.60 & 0.11 & 227.50 & -1.64 & 0.10 & 172.00 & -1.67 & 0.09 \\
\hline Item 13 & 186.50 & -2.70 & 0.01 & 236.00 & -0.15 & 0.88 & 167.00 & -2.86 & 0.00 & 224.00 & -0.43 & 0.67 \\
\hline Item 14 & 204.50 & -2.31 & 0.02 & 189.50 & -1.26 & 0.21 & 293.00 & -0.30 & 0.76 & 205.50 & -0.86 & 0.39 \\
\hline Item 15 & 213.00 & -2.22 & 0.03 & 149.00 & -2.25 & 0.02 & 183.00 & -2.52 & 0.01 & 237.50 & -0.10 & 0.92 \\
\hline Item 16 & 230.00 & -1.85 & 0.07 & 149.00 & -2.27 & 0.02 & 223.50 & -1.70 & 0.09 & 236.50 & -0.12 & 0.90 \\
\hline Item 17 & 289.50 & -0.69 & 0.49 & 184.00 & -1.39 & 0.16 & 306.00 & -0.04 & 0.97 & 182.00 & -1.43 & 0.15 \\
\hline Item 18 & 220.50 & -2.06 & 0.04 & 223.00 & -0.46 & 0.64 & 269.50 & -0.77 & 0.44 & 159.00 & -2.04 & 0.04 \\
\hline Item 19 & 155.50 & -3.28 & 0.00 & 178.00 & -1.54 & 0.12 & 220.50 & -1.74 & 0.08 & 199.50 & -1.02 & 0.31 \\
\hline Item 20 & 229.00 & -1.85 & 0.06 & 190.00 & -1.26 & 0.21 & 237.50 & -1.42 & 0.16 & 213.00 & -0.70 & 0.49 \\
\hline Item 21 & 238.00 & -1.69 & 0.09 & 129.00 & -2.75 & 0.01 & 287.00 & -0.42 & 0.67 & 159.50 & -2.01 & 0.05 \\
\hline Item 22 & 228.00 & -1.89 & 0.06 & 150.50 & -2.25 & 0.03 & 201.00 & -2.15 & 0.03 & 212.00 & -0.72 & 0.48 \\
\hline Item 23 & 227.50 & -1.91 & 0.06 & 228.00 & -0.34 & 0.73 & 273.50 & -0.69 & 0.49 & 238.00 & -0.08 & 0.93 \\
\hline Item 24 & 223.50 & -1.98 & 0.05 & 213.00 & -0.69 & 0.49 & 262.50 & -0.91 & 0.36 & 207.00 & -0.83 & 0.41 \\
\hline Item 25 & 203.50 & -2.39 & 0.02 & 165.50 & -1.84 & 0.07 & 265.50 & -0.85 & 0.40 & 220.50 & -0.52 & 0.60 \\
\hline Item 26 & 231.50 & -1.81 & 0.07 & 240.00 & -0.05 & 0.96 & 215.50 & -1.84 & 0.07 & 201.00 & -0.98 & 0.33 \\
\hline Item 27 & 228.50 & -1.86 & 0.06 & 207.50 & -0.85 & 0.40 & 298.00 & -0.21 & 0.83 & 215.50 & -0.65 & 0.52 \\
\hline Item 28 & 273.50 & -1.03 & 0.31 & 226.50 & -0.39 & 0.70 & 236.00 & -1.49 & 0.14 & 182.00 & -1.51 & 0.13 \\
\hline Item 29 & 318.50 & -0.13 & 0.90 & 239.00 & -0.07 & 0.94 & 301.00 & -0.14 & 0.89 & 183.50 & -1.45 & 0.15 \\
\hline
\end{tabular}

When Table 7 is examined, it is seen that the self-regulatory strategies of particularly the $1^{\text {st }}$ class prospective teachers vary significantly according to gender. In addition, it is seen that in other class levels, the meaningfulness of this difference is encountered in several items. When examined in more detail, it is seen that the responses given by $1^{\text {st }}$ class prospective teachers to the items "effort regulation" (I1-I3) dimension are similar, however, the responses given to the items in "attention focusing" (I5, I7, I8), "using additional resource" (I9, I10), "motivation regulation" (I13, I14, I15, I16), "summarizing strategy" (I18, I19), "self-instruction" (I20-I22), "planning" (I23-I26) and "highlighting strategy" (I17) are significantly different. When Table 7 is examined in order to determine of which gender the difference is in favor, it is found that all self-regulatory strategies of male prospective teachers are significantly higher than female prospective teachers. When the situation is examined for the $2^{\text {nd }}$ class prospective teachers, it is seen that the self-regulatory strategies of female prospective teachers are significantly higher than male prospective teachers in "motivation regulation" (I15, I16), "self-instruction" (I21, I22) and "planning" (I25) dimensions. When responses of $3^{\text {rd }}$ class prospective teachers in "motivation regulation" (I13, I15 and I16), "self-instruction" (I22) and "planning" (I26) dimensions, it is seen that self-regulatory strategies of female prospective teachers are significantly higher than those of male prospective teachers similar to the $2^{\text {nd }}$ class prospective teachers. When responses of the $4^{\text {th }}$ class prospective teachers to the items are examined, it is seen that self-regulatory strategies of male prospective teachers are higher than those of female prospective teachers in "effort regulation" (I1-I3), "motivation regulation" (I12) and "self-instruction" (I21) dimensions. However, self-regulatory strategies of female prospective teachers in "summarizing strategy" (I18) dimension are significantly higher than those of male prospective teachers.

\subsection{Descriptive Statistics of CSES According to Gender}

Within the scope of the study, female and male prospective teachers' reactions to CSES items were examined via descriptive statistics and findings were given in Table 8. 
Table 8. Descriptive statistics of CSES item scores according to gender

\begin{tabular}{|c|c|c|c|c|c|c|c|c|c|c|c|}
\hline \multirow{2}{*}{\multicolumn{2}{|c|}{ Items }} & & \multirow{2}{*}{ Gender } & \multicolumn{2}{|c|}{ Class 1} & \multicolumn{2}{|c|}{ Class 2} & \multicolumn{2}{|c|}{ Class 3} & \multicolumn{2}{|c|}{ Class 4} \\
\hline & & & & $\overline{\bar{X}}$ & SD & $\overline{\bar{X}}$ & SD & $\bar{X}$ & SD & $\overline{\bar{X}}$ & SD \\
\hline \multirow{2}{*}{\multicolumn{2}{|c|}{ Item 1}} & \multirow{2}{*}{$\begin{array}{l}\text { Applying a set of chemistry rules to different } \\
\text { elements of the periodic table }\end{array}$} & Male & 1.73 & 0.67 & 3.36 & 0.49 & 3.29 & 0.71 & 3.96 & 0.64 \\
\hline & & & & 2.96 & 0.68 & 4.18 & 0.59 & 4.18 & 0.50 & 4.67 & 0.48 \\
\hline \multirow{2}{*}{\multicolumn{2}{|c|}{ Item 2}} & \multirow{2}{*}{$\begin{array}{l}\text { Tutoring another student in a first year chemistry } \\
\text { course }\end{array}$} & & 2.65 & 1.20 & 4.05 & 0.65 & 3.75 & 0.52 & 3.96 & 0.71 \\
\hline & & & & 2.56 & 0.87 & 3.82 & 0.73 & 4.14 & 0.64 & 4.24 & 0.77 \\
\hline \multirow{10}{*}{ 包 } & \multirow{2}{*}{ Item 3} & \multirow{2}{*}{$\begin{array}{l}\text { Explaining something that you learning in this } \\
\text { chemistry course to another person }\end{array}$} & & 3.08 & 1.06 & 3.86 & 0.83 & 4.18 & 0.55 & 4.13 & 0.55 \\
\hline & & & & 3.52 & 0.82 & 4.18 & 0.50 & 4.18 & 0.66 & 4.10 & 0.83 \\
\hline & \multirow{2}{*}{ Item 4} & \multirow{2}{*}{$\begin{array}{l}\text { Choosing an appropriate formula to solve a } \\
\text { chemistry problem }\end{array}$} & & 4.00 & 0.89 & 4.14 & 0.71 & 3.82 & 0.67 & 4.13 & 0.69 \\
\hline & & & & 3.88 & 0.53 & 4.09 & 0.61 & 4.32 & 0.65 & 4.14 & 0.65 \\
\hline & \multirow[b]{2}{*}{ Item 5} & \multirow{2}{*}{$\begin{array}{l}\text { After reading an article about a chemistry } \\
\text { experiment, you writing a summary of the main } \\
\text { points }\end{array}$} & & 2.73 & 0.87 & 3.86 & 0.64 & 4.11 & 0.63 & 3.87 & 0.46 \\
\hline & & & & 2.68 & 0.90 & 4.09 & 0.75 & 4.23 & 0.61 & 3.86 & 0.48 \\
\hline & \multirow{2}{*}{ Item 6} & \multirow{2}{*}{$\begin{array}{l}\text { After watching a television documentary dealing } \\
\text { with some aspect of chemistry experiment, } \\
\text { writing a summary of its main points }\end{array}$} & & 2.50 & 0.86 & 3.36 & 0.58 & 4.07 & 0,66 & 3.65 & 0.57 \\
\hline & & & & 2.72 & 0.79 & 3.86 & 0.77 & 4.05 & 0.84 & 3.95 & 0.59 \\
\hline & \multirow[b]{2}{*}{ Item 7} & \multirow{2}{*}{$\begin{array}{l}\text { After listening to a public lecture regarding some } \\
\text { chemistry topic, explaining its main ideas to } \\
\text { another person }\end{array}$} & & 2.23 & 0.86 & 4.00 & 0.82 & 4.11 & 0.63 & 3.91 & 0.51 \\
\hline & & & & 2.40 & 0.82 & 4.27 & 0.70 & 4.09 & 0.68 & 3.71 & 0.46 \\
\hline \multirow{6}{*}{$\frac{\nabla}{\varpi}$} & \multirow{2}{*}{ Item 8} & \multirow{2}{*}{$\begin{array}{l}\text { Achieving a passing grade in a chemical hazards } \\
\text { course }\end{array}$} & & 2.31 & 0.88 & 4.05 & 0.58 & 3.86 & 0.59 & 3.96 & 0.71 \\
\hline & & & & 2.60 & 0.87 & 4.18 & 0.59 & 4.14 & 0.83 & 4.29 & 0.64 \\
\hline & & & & 3.77 & 0.51 & 4.14 & 0.77 & 4.04 & 0.51 & 4.13 & 0.55 \\
\hline & Item 9 & & & 3.56 & 0.51 & 4.09 & 0.68 & 4.23 & 0.53 & 3.62 & 0.50 \\
\hline & & & & 3.58 & 0.64 & 3.86 & 0.71 & 4.07 & 0.47 & 4.39 & 0.66 \\
\hline & & & & 3.56 & 0.51 & 4.00 & 0.76 & 4.27 & 0.70 & 4.29 & 0.56 \\
\hline & & & & 3.19 & 0.80 & 3.64 & 0.85 & 3.71 & 0.76 & 3.70 & 0.47 \\
\hline & & & & 2.88 & 0.78 & 3.64 & 0.73 & 4.05 & 0.72 & 3.62 & 0.50 \\
\hline & & Knov & & 3.81 & 0.57 & 4.32 & 0.72 & 4.11 & 0.63 & 4.04 & 0.71 \\
\hline & & & & 3.60 & 0.58 & 4.23 & 0.69 & 4.05 & 0.65 & 4.33 & 0.73 \\
\hline & & & & 3.15 & 0.78 & 3.95 & 0.49 & 4.21 & 0.74 & 4.13 & 0.69 \\
\hline & & & & 3.24 & 0.72 & 3.95 & 0.65 & 4.09 & 0.53 & 4.48 & 0.75 \\
\hline & & & & 2.00 & 0.94 & 4.14 & 0.64 & 3.96 & 0.43 & 3.87 & 0.55 \\
\hline & & & & 2.32 & 0.85 & 4.23 & 0.69 & 4.27 & 0.55 & 3.62 & 0.50 \\
\hline & & & & 3.08 & 0.89 & 3.59 & 1.01 & 3.64 & 0.68 & 3.83 & 0.58 \\
\hline & 115 & & & 2.96 & 0.84 & 3.55 & 0.80 & 3.82 & 0.66 & 4.24 & 0.62 \\
\hline & & Determining the appropriate units for a & $\mathrm{M}$ & 3.42 & 0.76 & 3.91 & 0.61 & 3.68 & 0.67 & 3.83 & 0.39 \\
\hline & die & & & 3.64 & 0.49 & 4.14 & 0.64 & 3.91 & 0.75 & 3.90 & 0.54 \\
\hline & & & & 3.65 & 0.63 & 3.73 & 0.77 & 3.71 & 0.60 & 3.74 & 0.45 \\
\hline & & & Female & 3.76 & 0.44 & 4.00 & 0.53 & 4.14 & 0.64 & 3.90 & 0.54 \\
\hline
\end{tabular}

When Table 8 was examined, it was seen that there are differences in the answers of male and female prospective teachers. In order to examine the meaningfulness of the difference in male and female prospective teachers' answers, Mann-Whitney U test was done and the related results were given in Table 9.

Table 9. Mann-Whitney U test results of CSES according to gender in class levels

\begin{tabular}{lcccccccccccc}
\hline Items & & Class 1 & \multicolumn{1}{c}{ Class 2 } & \multicolumn{4}{c}{ Class 3 } & \multicolumn{3}{c}{ Class 4 } \\
\hline Item 1 & $\mathbf{U}$ & $\mathbf{Z}$ & $\boldsymbol{P}$ & $\mathbf{U}$ & $\mathbf{Z}$ & $\boldsymbol{p}$ & $\mathbf{U}$ & $\mathbf{Z}$ & $\boldsymbol{p}$ & $\mathbf{U}$ & $\mathbf{Z}$ & $\boldsymbol{p}$ \\
Item 2 & 38 & -4.897 & 0,000 & 86 & -4.032 & 0,000 & 114 & -4.224 & 0.000 & 105 & -3.538 & 0.000 \\
Item 3 & 24.5 & -0.246 & 0.806 & 199 & -1.109 & 0.268 & 211.5 & -2.215 & 0.027 & 190.5 & -1.29 & 0.197 \\
Item 4 & 280 & -1.663 & 0.096 & 196,5 & -1.272 & 0.203 & 303.5 & -0.102 & 0.919 & 236.5 & -0.134 & 0.894 \\
Item 5 & 318.5 & -0.13 & 0.338 & 231,5 & -0.277 & 0.782 & 193.5 & -2.522 & 0.012 & 240 & -0.039 & 0.969 \\
Item 6 & 273.5 & -1.045 & 0.296 & 150.5 & -2.353 & 0.019 & 304.5 & -0.075 & 0.940 & 188 & -1.534 & 0.125 \\
Item 7 & 294.5 & -0.612 & 0.541 & 197 & -1.131 & 0.258 & 305 & -0.066 & 0.947 & 199.5 & -1.27 & 0.204 \\
Item 8 & 269.5 & -1.107 & 0.268 & 214 & -0.785 & 0.432 & 244.5 & -1.351 & 0.177 & 181 & -1.564 & 0.118 \\
Item 9 & 250 & -1.751 & 0.080 & 232 & -0.254 & 0.799 & 256 & -1.292 & 0.196 & 138 & -2.905 & 0.004 \\
Item 10 & 305.5 & -0.43 & 0.668 & 218 & -0.61 & 0.542 & 249 & -1.359 & 0.174 & 214.5 & -0.714 & 0.475 \\
Item 11 & 250.5 & -1.521 & 0.128 & 240 & -0.051 & 0.959 & 232.5 & -1.583 & 0.113 & 223 & -0.529 & 0.597 \\
Item 12 & 276 & -1.1 & 0.271 & 223 & -0.488 & 0.626 & 293 & -0.335 & 0.738 & 187.5 & -1.374 & 0.169 \\
Item 13 & 307 & -0.365 & 0.715 & 241 & -0.029 & 0.977 & 271 & -0.811 & 0.417 & 173.5 & -1.738 & 0.082 \\
Item 14 & 256 & -1.373 & 0.170 & 223 & -0.498 & 0.619 & 222.5 & -2.178 & 0.029 & 178.5 & -1.905 & 0.057 \\
Item 15 & 293.5 & -0.636 & 0.525 & 238 & -0.099 & 0.921 & 263 & -0.969 & 0.333 & 161 & -2.177 & 0.029 \\
Item 16 & 286.5 & -0.841 & 0.400 & 197.5 & -1.202 & 0.229 & 256.5 & -1.096 & 0.273 & 226.5 & -0.483 & 0.629 \\
Item 17 & 297 & -0.651 & 0.515 & 185 & -1.488 & 0.137 & 205 & -2.274 & 0.023 & 207.5 & -1.028 & 0.304 \\
\hline
\end{tabular}


When Table 9 was examined, it was seen that there is a significantly difference in the male and female prospective teachers' answers for I1, I2, I4, I9, I14 and I17 items. Content of these items and the findings obtained after examining them with the descriptive statistics in Table 8 are as follows:

When the answers given at all class levels to I1 item of CSES was examined, it was seen that female prospective teachers have a higher self efficacy compared to male prospective teachers in all class levels (GPA [freshman]: Male=1.73, Female=2.96; [sophomore]: Male=3.36, Female=4.18; [junior]: Male=3.29, Female=4.18; [senior]: Male $=3.96$, Female $=4.67$ ). When results were examined, it was seen that prospective teachers in both groups (male and female) become more self-efficacy in their answers to this item as their class level increases.

When the answers given to the I2 item of CSES was examined, it was seen that male prospective teachers are especially self-efficacy in their sophomore years (GPA [sophomore]: Male=4.05), however, their self-efficacy to teach freshmen drops as their class level increases. The self-efficacy that is aimed in this item shows one's belief in their knowledge related to information and concepts of basic chemistry. By looking at the result for the I 2 whether there is a difference at all class levels according to gender, it was seen that female juniors have a higher self efficacy compared to male juniors (GPA [junior]: Male $=3.75$, Female=4.14). However, no such significantly difference is present between female and male seniors. When the answers given to the I4 item of CSES was examined, it was seen that female juniors have a higher self efficacy in collecting data related to an experiment compared to male juniors (GPA [junior]: Male $=4.05$, Female $=4.32$ ). When the answers given to the I9 item of CSES was examined, it was seen that male seniors have a higher self efficacy compared to female seniors (GPA [senior]: Male $=4.13$, Female $=3.62$ ). When all the answers given to all items are examined, it can be observed that female prospective teachers have a high self-efficacy especially in the items of the second part [Self Efficacy in Learning Chemistry Skills] of CSES. When the reactions given to the I14 of CSES (GPA [junior]: Male $=3.96$, Female $=4.27$ ) and the answers given to the I17 item $($ GPA [junior]: Male $=3.71$, Female $=4.14$ ) were examined, it was seen that female juniors have a higher self-efficacy compared to male juniors.

\subsection{Relationship between Self-regulatory Strategies and Chemistry Self-efficacy}

The correlation matrix was arranged separately for class level as the prospective science teachers in different class levels of university. Obtained correlation matrix was presented in Table 10.

Table 10. Relationship between chemistry self-efficacy and self-regulatory strategies according to class level

\begin{tabular}{rcrrrrrrrr}
\hline Class & Self Efficacy & \multicolumn{1}{c}{$\mathbf{F 1}^{\mathbf{a}}$} & \multicolumn{1}{c}{$\mathbf{F 2}^{\mathbf{a}}$} & $\mathbf{F 3}^{\mathbf{a}}$ & $\mathbf{F 4}^{\mathbf{a}}$ & \multicolumn{1}{c}{$\mathbf{F 5}^{\mathbf{a}}$} & $\mathbf{F 6}^{\mathbf{a}}$ & $\mathbf{F 7}^{\mathbf{a}}$ & $\mathbf{F 8}^{\mathbf{a}}$ \\
\hline \multirow{5}{*}{ Class 1 } & Self Efficacy & 0.20 & 0.16 & 0.22 & 0.22 & 0.22 & $.322^{*}$ & $.323^{*}$ & $.523^{*}$ \\
& SACT & -0.01 & 0.01 & -0.08 & -0.17 & -0.07 & -0.18 & -0.01 & 0.12 \\
& SLCT & 0.17 & 0.18 & 0.10 & 0.15 & 0.20 & $.320^{*}$ & 0.07 & 0.22 \\
& SACS & 0.13 & 0.24 & 0.15 & 0.27 & 0.02 & $.278^{*}$ & $.378^{*}$ & $.400^{*}$ \\
& SLCS & 0.11 & -0.09 & 0.27 & 0.21 & $.298^{*}$ & 0.24 & 0.24 & $.355^{*}$ \\
\hline \multirow{5}{*}{ Class 2 } & Self Efficacy & -0.04 & 0.28 & 0.21 & $.337^{*}$ & 0.03 & -0.07 & 0.27 & 0.04 \\
& SACT & -0.03 & 0.13 & 0.23 & $.414^{*}$ & 0.10 & -0.01 & $.310^{*}$ & -0.12 \\
& SLCT & -0.19 & 0.26 & 0.14 & 0.20 & -0.02 & -0.15 & $.322^{*}$ & 0.07 \\
& SACS & 0.21 & 0.23 & 0.21 & 0.16 & -0.06 & -0.10 & 0.02 & 0.13 \\
& SLCS & -0.08 & 0.23 & 0.08 & 0.28 & 0.08 & 0.05 & 0.16 & 0.04 \\
\hline \multirow{5}{*}{ Class 3 } & Self Efficacy & -0.01 & $.325^{*}$ & $.617^{*}$ & $.599^{*}$ & $.290^{*}$ & $.394^{*}$ & $.453^{*}$ & 0.23 \\
& SACT & -0.08 & 0.25 & $.588^{*}$ & $.466^{*}$ & 0.22 & $.371^{*}$ & $.399^{*}$ & 0.20 \\
& SLCT & 0.06 & $.301^{*}$ & $.690^{*}$ & $.613^{*}$ & 0.21 & $.370^{*}$ & $.513^{*}$ & 0.21 \\
& SACS & 0.02 & $.333^{*}$ & $.293^{*}$ & $.410^{*}$ & 0.25 & $.298^{*}$ & $.324^{*}$ & 0.21 \\
& SLCS & -0.03 & 0.14 & $.373^{*}$ & $.389^{*}$ & 0.22 & 0.20 & 0.20 & 0.11 \\
\hline & Self Efficacy & -0.19 & 0.03 & 0.23 & 0.01 & 0.16 & 0.08 & 0.26 & 0.15 \\
& SACT & -0.16 & 0.08 & 0.26 & -0.01 & 0.06 & 0.12 & 0.07 & 0.08 \\
& SLCT & 0.01 & -0.17 & -0.07 & -0.12 & 0.07 & 0.01 & 0.15 & 0.23 \\
& SACS & -0.14 & 0.23 & $.466^{*}$ & 0.13 & $.373^{*}$ & 0.18 & $.375^{*}$ & $.338^{*}$ \\
& SLCS & -0.27 & -0.02 & 0.06 & 0.05 & 0.00 & -0.05 & 0.19 & -0.20 \\
\hline
\end{tabular}

${ }^{\mathrm{a}}$ F1: Effort Regulation, F2: Attention Focusing, F3: Using Additional Resource, F4: Motivation Regulation, F5: Summarizing Strategy, F6: Self-Instruction, F7: Planning, F8: Highlighting Strategy. ${ }^{*} p<\alpha$

When Table 10 is examined, it is seen that self-efficacy levels of the $3^{\text {rd }}$ class prospective teachers is significantly related with "attention focusing, using additional resource, motivation regulation, summarizing strategy, self-instruction and planning" self-regulatory strategies. When other class levels are examined, it is seen that the chemistry self-efficacy levels of the $1^{\text {st }}$ class prospective teachers are related with "self-instruction and highlighting strategy", those of $2^{\text {nd }}$ class prospective teachers are related with "motivation regulation" self-regulatory strategies. However, it is seen that the chemistry self-efficacy levels of the $4^{\text {th }}$ class prospective teachers aren't related with any self-regulatory strategy.

Within the scope of the research, multiple regression analysis was used in order to examine the predictive power and level of self-regulatory strategies of prospective science teachers for chemistry self-efficacy levels. As the prospective teachers included in the research group were attending different class levels, data were weighted in the analyses 
according to the class level. As a result of the weighting, a correlation matrix was constituted based on the data weighted according to the class level in order to examine the relationship between predicted variable chemistry self-efficacy levels of prospective teachers and self-regulatory strategies which were predictive variables. Obtained correlation matrix was presented in Table 11.

Table 11. Relationship between self-regulatory strategies and chemistry self-efficacy weighted according to the class level

\begin{tabular}{lrrrrrrrr}
\hline & Self-Efficacy & F1 & F2 & F3 & F4 & F5 & F6 & F7 \\
\hline Effort Regulation (F1) & 0.002 & & & & & & & \\
Attention Focusing (F2) & $.161^{* *}$ & 0,04 & & & & & & \\
Using Additional Resource (F3) & $.306^{* *}$ & $.115^{*}$ & $.291^{* *}$ & & & & & \\
Motivation Regulation (F4) & $.180^{* *}$ & 0.036 & $.518^{* *}$ & $.448^{* *}$ & & & & \\
Summarizing Strategy (F5) & $.135^{* *}$ & -0.001 & $.215^{* *}$ & $.479^{* *}$ & $.390^{* *}$ & & & \\
Self-Instruction (F6) & $.190^{* *}$ & $.168^{* *}$ & $.324^{* *}$ & $.386^{* *}$ & $.288^{* *}$ & $.488^{* *}$ & & \\
Planning (F7) & $.264^{* *}$ & -0.015 & $.372^{* *}$ & $.518^{* *}$ & $.615^{* *}$ & $.603^{* *}$ & $.376^{* *}$ & \\
Highlighting Strategy (F8) & $.249^{* *}$ & $.180^{* *}$ & $.481^{* *}$ & $.393^{* *}$ & $.350^{* *}$ & $.395^{* *}$ & $.492^{* *}$ & $.363^{* *}$ \\
\hline
\end{tabular}

When Table 11 is examined, it is seen that the chemistry self-efficacy is related with "attention focusing, using additional resource, motivation regulation, summarizing strategy, self-instruction, planning and highlighting strategy" from self-regulatory strategies. Considering that there should be a linear relationship between the predicted variable and the predictive variables, which is one of the basic assumptions of multiple regression analysis, it is seen that the variables which are suitable to be included in multiple regression analysis are "using additional resource (.31), planning (.26) and highlighting strategy (.25)" (Kalayc1, 2008).

Findings obtained as a result of reverse staged multiple linear regression analysis weighted according to the class level due to the verification of required assumptions are given in Table 12.

Table 12. Reverse staged multiple linear regression analysis weighted according to the class level

\begin{tabular}{lccccccc}
\hline \multicolumn{1}{c}{ Regression Model } & B & t & $\boldsymbol{p}$ & $\mathbf{r}$ & Partial r & Tolerance & VIF \\
\hline Constant & 3.24 & 21.60 & 0.000 & & & & \\
Using Additional Resource & 0.25 & 3.27 & 0.001 & 0.31 & 0.23 & 0.846 & 1.183 \\
Highlighting Strategy & 0.15 & 2.03 & 0.044 & 0.25 & 0.15 & 0.846 & 1.183 \\
\hline$F_{(2,186)}=11.870$ & \multicolumn{5}{c}{$p=.000$} \\
$\mathrm{R}=0.34$ & Corrected $\mathrm{R}^{2}=0.11$ & & & \\
\hline
\end{tabular}

When Table 12 is examined, it is seen that as "planning" self-regulatory learning strategy isn't significant, it was removed from the model in the model in which predictive power of "using additional resource, planning and highlighting strategy" self-regulatory strategies of prospective science teachers for chemistry self-efficacy levels, the chemistry self-efficacy level is explained by fixed regression model which includes "using additional resource and highlighting strategy" self-regulatory strategies. According to this, $11 \%$ of chemistry self-efficacy levels of prospective science teachers can be explained by the regression equation as Chemistry Self-Efficacy level $=0.25 \times$ (Using Additional Resource) +0.15 (Highlighting Strategy) +3.24 . It is seen that the obtained regression model is significantly and the model's ability to explain the self-efficacy levels of prospective teachers is low.

\section{Discussion}

In this study, the aim is to determine whether there is a significantly difference in the self-regulatory strategies used by prospective science teachers $\left(1^{\text {st }}, 2^{\text {nd }}, 3^{\text {rd }}\right.$ and $4^{\text {th }}$ class $)$ while studying for chemistry lesson and their chemistry self efficacy who have taken General Chemistry according to gender and class level. Departing from this basic purpose, for the first research question of the study, it was observed in Table 2 and 3 that the highest participation in the behaviors in "motivation regulation" dimension of the self-regulatory strategies of prospective teachers which included only "I motive myself to study more thinking I will get good classes" and "I motive myself to study in order to be loved by my teacher" items was realized by the $1^{\text {st }}$ class prospective teachers. However, it was observed that the highest participation in the behaviors in all other dimensions was realized as the class level increased, particularly by $4^{\text {th }}$ class prospective teachers. The fact that responses given to items in each dimension of self-regulatory strategies used in studying indicated high participation as the class level increased is parallel with the findings obtained from some related studies. It was stated in our findings obtained considering gender factor that in the study carried out by Zimmerman and Martines-Pons (1990) in which the relation between academic competences and self-regulatory strategies if students in $5^{\text {th }}, 8^{\text {th }}$ and $11^{\text {th }}$ class levels was examined in terms of gender and class level, female students indicated higher participation in almost all dimensions of self-regulatory strategies. In the related study, it was also defined that the lowest participation in the related items in each dimension of SRSS was realized by $5^{\text {th }}$ class students, they indicated significantly differences compared to $8^{\text {th }}$ and $11^{\text {th }}$ classes, however; there was no significantly difference between $8^{\text {th }}$ and $11^{\text {th }}$ classes. Again, in a study in which motivational beliefs, test anxiety, self-efficacy and self-regulatory strategies of 
students in $9^{\text {th }}, 10^{\text {th }}, 11^{\text {th }}$ and $12^{\text {th }}$ classes were examined in terms of ethnical groups and class level, it was observed that there was a higher participation in using self-regulatory strategies in favor of $12^{\text {th }}$ class level in the interval from $9^{\text {th }}$ class level to $12^{\text {th }}$ class level (Ongowo \& Hungi, 2014).

When the meaningfulness of prospective teachers' reactions to CSES were examined for the second research question of the study in Table 4 and Table 5, it was seen that the difference in the answers of prospective teachers at different class levels was significantly for every item in CSES except for one item in "applying theory of chemistry" and one item in "learning chemistry skills" $(p<. \alpha)$. When Table 5 was examined for the results that are the outcome of the analysis which was done to determine at what class level the difference occurs, it was observed that in all items except those in some sub-dimensions of CSES (I4, I5, I6, I7, and I17 items) $1^{\text {st }}$ class prospective teachers have a significantly low self efficacy compared to those who are at more advanced classes. According to Table 4 and 5, there is an important point that should be noted on I5, I6, I7, I9 and I14 items of CSES. The results show that chemical self-efficacy of $2^{\text {nd }}$ and $3^{\text {th }}$ class prospective teachers are better than $4^{\text {th }}$ class prospective teachers. For this general result, curriculum of the related department of the participant students was examined. According to the curriculum, students are supposed to take General Chemistry (I) and (II) and General Chemistry Laboratory (I) and (II) for two semesters during their $1^{\text {st }}$ class. At this same department, there are more variations in chemistry-related courses in the $2^{\text {nd }}$ class, General Chemistry (III): Analytical Chemistry and General Chemistry (IV): Organic Chemistry. In the $3^{\text {rd }}$ class at this department take a lab class, which aims to transform their basic knowledge in all disciplines (physics, chemistry and biology) to skills Science Lab Applications (I) and (II), and a compulsory elective course which focuses on the importance of daily chemistry (Special Topics in Chemistry). $4^{\text {th }}$ class period is the last term of education and learning received by our prospective teachers just before a term in which they will practice their profession. However, due to the nature of the curriculum in the $4^{\text {th }}$ class, students take classes related to their field - Biology - and classes related to education sciences that focus on "Professional Teaching Knowledge". As such, they do not have classes that focus on "Chemistry". In our country, before practicing the profession of teaching, our prospective teachers go through certain stages; PPST (Public Personnel Selection Test) and PTKT (Professional Teaching Knowledge Test). Our prospective teachers are responsible for all topics related to the department they graduate from (Physics, Chemistry and Biology) particularly in one of those two exams called PTKT. Therefore, when our prospective teachers are in the senior class, they prepare for both course period exams and the exams defined above using additional resources related to all courses they take in their education-teaching period. Thus, we can say that the reason for the significantly lower self-efficacy of prospective teachers in the $4^{\text {th }}$ class for five items (I5, I6, I7, I9 and I14) in CSES compared to prospective teachers in the $2^{\text {nd }}$ and $3^{\text {rd }}$ classes is that they do not have "chemistry" lessons in the $4^{\text {th }}$ class. Bautista (2011) explains the generally low self-efficacy of prospective primary school teachers with the fact that they have little to zero teaching experience and that they have an education that is comprised of weak conceptual comprehension. One of the aims of the science courses at the department of primary school education is to increase teachers' self-efficacy because the basis for a successful teaching is high self-efficacy in teachers (Bhattacharyya, Volk \& Lumpe, 2009). Palmer (2006) emphasizes the necessity of additional resources for self-efficacy, namely, (a) mastery in cognitive content (b) mastery in cognitive pedagogy, and role-playing in in-class activities. As such, the fact that chemistry self-efficacy of prospective science teachers is low especially at freshman year can be related to the resources that are influential in the emergence of self efficacy, as Palmer (2006) also indicates in his study. The fact that freshmen are new at university when they take the basic lab classes in which they put into practice their theoretical learning and basic know how into practice can be the reason for their lower self efficacy compared to the students at later years.

According to the third research questions' findings obtained regarding whether the self-regulatory strategies of prospective teachers in different class levels within the scope of the study varied depending on the gender, differences were observed in answers given to the items by female and male prospective teachers in the same class level. According to the findings obtained from Table 6 and Table 7 following the analyses carried out depending on the gender, all self-regulatory strategies of $1^{\text {st }}$ class male prospective teachers in the Department of Science Education for studying for chemistry lesson were found to be higher than those of female prospective teachers. In addition, in $2^{\text {nd }}$ and $3^{\text {rd }}$ class levels, it was observed that the self-regulatory strategies of female prospective teachers were higher than those of male prospective teachers in a few items. The all findings obtained for $2^{\text {nd }}$ and $3^{\text {rd }}$ classes are parallel with the previous studies indicating gender differences in favor of girls. For example, Zimmerman and Martinez-Pons (1990) observed in their studies that female students used self-regulatory strategies (target determination, planning strategies, keeping records and self-observation) more than male students did. Similarly, Ablard and Lipschultz (1998) stated that female students used self-regulatory strategies such as "personal regulation or optimizing the environment" more often. Again, in a study in which female and male students were compared in terms of using self-regulatory strategies (Virtanen \& Nevgi, 2010), it was defined that female students participated slightly higher in "Forethought of Learning and in the Strategies in Learning" dimensions than male students. Nevgi (2002) and Niemi, Nevgi and Virtanen (2003) determined in their studies that female students used the key words while studying more than male students do and they were more 
organized than male students were, thus they combine the information they learned in the early stages of their studies with newly acquired information more actively. Again, Kadıŏlu, Uzuntiryaki and Çapa-Aydın (2011) observed in their studies that female students used self-regulatory strategies while studying for the chemistry lesson more than male students did. Likewise, Şenler and Sungur-Vural (2014) defined in their studies that female prospective teachers used the strategies such as "planning, monitoring and evaluating" in their own learning process more than male prospective teachers did and they made more effort. Batdal Karaduman, Güder, Özsoy-Güneş and Kırbaşlar (2015) observed in their studies that in using self-regulatory strategies, female prospective teachers indicated higher participation in the dimensions of "planning and lack of self-directedness" more than male prospective teachers did. However, when the responses given to the items by $4^{\text {th }}$ class prospective teachers in our study are examined, it is seen that self-regulatory strategies of male prospective teachers were significantly higher than those of female prospective teachers in terms of items in a number of dimensions but only in "Summarizing" strategy, female prospective teachers participated higher than male prospective teachers did.

Within the scope of the study, reactions of male and female prospective teachers to the items of CSES for the fourth research question were examined via descriptive statistics, and when the results given in Table 8 were examined, it was seen that there are differences in the answers of male and female prospective teachers. In order to examine the meaningfulness of the difference in answers, Mann-Whitney $U$ test was applied, and the related results were given in Table 9. When Table 8 and Table 9 were examined together so as to see the differences in class levels according to gender, it was observed that students from both gender groups have the highest self-efficacy at $3^{\text {rd }}$ and $4^{\text {th }}$ classes according to the answers given to all items of the CSES. When the results in Table 8 and Table 9 were examined, it was observed that $2^{\text {nd }}, 3^{\text {rd }}$ and $4^{\text {th }}$ classes have a higher self-efficacy throughout the whole scale compared to the $1^{\text {st }}$ class. When Table 8 was examined, it was seen that there is a significantly difference in the answers given by male and female prospective teachers at all class levels in SACT sub-dimension for I1 item, in the $3^{\text {rd }}$ class in SACT sub-dimension for I2 and I4 items, in SACS sub-dimension for I14 item and in SLCS sub-dimension for I17 item and in the $4^{\text {th }}$ class in SLCT sub-dimension for I9 item. Two items for which female prospective teachers present a higher self-efficacy than male prospective teachers are the ones that are about summarizing the results of what one learns after reading an article or attending a conference on chemistry. From the answers given to these two items, it can be drawn that female prospective teachers have a higher self-efficacy in their capacity to draw conclusions from a scientific article about a topic of which they have learned in theory in class. It was also observed that female prospective teachers have high self-efficacy in their skills to relate the important details of a chemistry-related topic they have listened to at a conference. Contrary to the findings of our study, female prospective teachers have a lower chemistry self-efficacy in many of the studies examined within the scope of the study (Lloyd, Walsh \& Yailagh, 2005; Michaelides, 2008; Pajares, 1996, 2002; Pintrich \& De Groot, 1990). In a study, Garcia (2010) expressed that while female students have a significantly lower self-efficacy at the beginning of the application process, there is a significantly increase in their self-efficacy at the end of the semester. Likewise, in their study, Dalgety and Coll (2006) found that male students have a higher self-efficacy compared to female students. In their interviews at the end of the study, Dalgety and Coll also expressed that male students gave more confident answers compared to female students.

Finally, for the fifth research question of this study, the relationship level between the self-regulatory strategies of prospective science teachers and their self-efficacies was tried to be determined. Departing from the basic purpose, according to the correlation matrix constituted according to different class levels of prospective teachers participating in the study, it was observed that the significantly relationship between self-regulatory strategies and chemistry self-efficacy was the most in the $3^{\text {rd }}$ class. According to data obtained from Table $10,3^{\text {rd }}$ class prospective teachers indicated significantly relationships in all sub-dimensions of CSES particularly between "using additional resource, motivation regulation, attention focusing and planning" self-regulatory strategies. Another result obtained in the study was that the relationship between certain sub-dimensions of both scales was indicated to be significantly in $1^{\text {st }}$ and $2^{\text {nd }}$ class prospective teachers respectively. According to the curriculum defined above in the Department of Science Education the $3^{\text {rd }}$ class prospective teachers take all chemistry-related lessons until the class they are attending. Therefore, it was an expected result that the relationship between the chemistry self-efficacy sub-dimensions and the self-regulatory strategies used by those in the $3^{\text {rd }}$ class while studying for chemistry lesson was meaningful. Self-efficacy levels of the $4^{\text {th }}$ grade prospective science teachers are not related to any of the self-regulatory strategies. When Table 10 was examined for another result obtained in the study, it was seen that the chemistry for the $4^{\text {th }}$ class, might say that $4^{\text {th }}$ class period is the last term of education and learning received by our prospective teachers just before a term in which they will practice their profession. Due to the nature of the curriculum in the $4^{\text {th }}$ class, prospective teachers take classes related to their field - Biology - and classes related to education sciences that focus on "Professional Teaching Knowledge." As such, they do not have classes that focus on "Chemistry". When our prospective teachers are in the $4^{\text {th }}$ class, they prepare for both course period exams and the exams defined above using supplementary resources related to all courses they take in their education-teaching period. Therefore, we can assume as 
the reason for the result we obtained from the study for the $4^{\text {th }}$ class prospective teachers that they become distanced from all "chemistry courses" due to their class level and they have different examinations to prepare beyond their graduate program. All these obtained results were in parallel with the results of many studies in literature in which the relations between the self-regulatory strategies of students/prospective teachers and both academic chemistry performances/chemistry success (Zimmerman \& Resemberg, 1997; Chen, 2002) and chemistry self-efficacy/teacher self-efficacy in were examined in terms of gender/class level/ethnical group (Alderman, 1999; Loong, 2012; Ongowo \& Hungi, 2014; Tunde, 2014; Zimmerman \& Martines-Pons, 1990). The results of the study by Tunde (2014) showed that self-regulated strategies have a significantly influence on predicting the students' academic performance in chemistry. Loong (2012) found that effort regulation was an effective instructional strategy in science class. Again, in a study in which motivational beliefs, test anxiety, self-efficacy and self-regulatory strategies of students in $9^{\text {th }}, 10^{\text {th }}, 11^{\text {th }}$ and $12^{\text {th }}$ grades were examined in terms of ethnical groups and grade level, it was observed that there was a higher participation in using self-regulatory strategies in favor of $12^{\text {th }}$ class level in the interval from $9^{\text {th }}$ class level to $12^{\text {th }}$ grade level (Ongowo \& Hungi, 2014). The study of Schunk and Zimmerman (1998) showed that compared to naïve self-regulators, skilful self-regulators set higher quality goals, have higher self-efficacy, can instruct themselves and monitor their learning process instead of using self-handicapping strategies, seek more opportunities for self-evaluation and reflect systematically on their learning experiences which positively influences new forethought processes. Again, given the wealth of studies, which have demonstrated the positive association between self-regulation, motivation, self-efficacy and academic performance (Yip, 2007; Zusho \& Edwards, 2011).

When Table 11 is examined, it is seen that the chemistry self-efficacy is related with "attention focusing, using additional resource, motivation regulation, summarizing strategy, self-instruction, planning and highlighting strategy" from self-regulatory strategies. Considering that there should be a linear relationship between the predicted variable and the predictive variables, which is one of the basic assumptions of multiple regression analysis, it is seen that the variables which are suitable to be included in multiple regression analysis are "using additional resource, planning and highlighting strategy". As a result, "planning" self-regulatory strategy was removed from the model in the model in which predictive power of "using additional resource", planning and highlighting strategy" self-regulatory strategies of prospective science teachers for chemistry self-efficacy levels as it wasn't significantly, the chemistry self-efficacy level is explained by fixed regression model which includes "using additional resource and highlighting strategy" self-regulatory strategies (Table 12). According to this, $11 \%$ of chemistry self-efficacy levels of related prospective teachers can be explained by these two self-regulatory strategies (using additional resource and highlighting strategy). Although the obtained regression model is significantly, it is seen that the model's ability to explain the self-efficacy levels of the prospective teachers is low. Motivational beliefs such as self-efficacy have been found to determine the choice, effort and degree of persistence for one's goal (Bandura, 1986). Zimmerman (2000), self-efficacy beliefs help students motivate to learning through the use of self-regulatory processes such as goal setting, self-monitoring, self-evaluation, and strategy use. According to many researches, it is emphasized that there is a relation between higher academic motivation of students and their having higher self-regulatory learning skills (Schmitz \&Wiese, 2006; Stoeger \& Ziegler, 2007; Velayutham, Aldridge \& Fraser, 2011).

This study was carried out with prospective science teachers. The self-regulation strategies and chemistry (or science, biology, physic self-efficacy etc.) of the science teachers on duty should be investigated and in-service training programs for the science teachers should be arranged for improving their self-regulation strategies or self-efficacy. Science teachers and prospective teachers should be trained on how to teach the self-regulation strategies to their students. Science teachers should engage students in complex, open ended activities, offer them choices and opportunities to control challenge and involve them in evaluating their own and other's work. The improvement of self-regulation strategies will also contribute to science knowledge of the students. Neber and Schommer-Aikins (2002) emphasized that science learning environment correlates significantly and positively with self-regulatory activities, the intrinsic value of science, and task goal orientation of the elementary school pupils. For this reason, the effects of self-regulation strategies increase of primary and secondary school students on science education should be investigated by the researcher. Among other recommendations that may be made departing from the results obtained within the scope of study; self-regulatory strategies used by students and their chemistry self-efficacies in different countries at the same class level while studying for chemistry lesson may be compared. While determining the scope of this recommendation, it is important to consider the determined targets and acquisitions for the education-teaching curricula of the related lesson and students in different countries. For example, Tang and Neber (2008) carried out a survey regarding the motivation and self-regulation in Chemistry learning among Americans, Chinese and Germans. The findings indicated that the American group scored higher than their Chinese and German counterparts did in motivational and self-regulatory characteristics. 


\section{References}

Ablard, K. E., \& Lipschultz, R. E. (1998). Self-regulated learning in high achieving students: Relations to advanced reasoning, achievement goals, and gender. Journal of Educational Psychology, 90, 94-101.

Alderman, M. K. (1999). Motivation for achievement possibilities for teaching and learning. Mahwah, N.J.: Lawrence Erlbaum Associates.

Andrew, S. (1998). Self-efficacy as a predictor of academic performance in science.Journal of Advanced Nursing, 27(3), 596-603. http://dx.doi.org/10.1046/j.1365-2648.1998.00550.x

Bandura, A. (1997). Self-efficacy: The exercise of control. New York: W.H. Freeman and Company.

Batdal, K. G., Güder, N., Özsoy-Güneş, Z., \& Kırbaşlar, F. G. (2015).Investigation of the relationship between study approaches and self-regulated learning skills of teacher candidates, INTE 2014, Procedia-Social and Behavioral Sciences, 174, 251-258.

Bautista, N. U. (2011). Investigating the use of vicarious and mastery experiences in influencing early childhood education majors' self-efficacy beliefs. Journal of Science Teacher Education, 22(4), 333-349. http://dx.doi.org/10.1007/s10972-011-9232-5

Bhattacharyya, S., Volk, T., \& Lumpe, A. (2009).The influence of an extensive inquiry-based field experience on prospective elementary student teachers' science teaching beliefs. Journal of Science Teacher Education, 20(3), 199-218. http://dx.doi.org/10.1007/s10972-009-9129-8

Boekaerts, M. (1999). Self-regulated learning: Where we are today. International Journal of Educational Research, 31(6), 445-457.

Boekaerts, M., \& Cascallar, E. (2006). Hoa far have we moved toward the integration of theory and practive in self regulation, Educational Pychology Review, 18, 199-210.

Boyd, M. (1990). The relationship between self-efficacy, self-esteem and anxiety in high school chemistry students (Unpublished doctoral dissertation), Murray State University, Murray, Kentucky.

Britner, S. L. (2008). Motivation in high school science students: a comparison of gender differences in life, physical, and earth science classes. Journal of Research in Science Teaching, 45(8), 955-970. http://dx.doi.org/10.1002/tea.20249

Britner, S. L., \& Pajares, F. (2001). Self-efficacy beliefs, motivation, race and gender in middle school science. Journal of Women and Minorities in Science and Engineering, 7(4), 271-285.

http://dx.doi.org/10.1615/JWomenMinorScienEng.v7.i4.10

Büyükduman, F. İ. (2006). The relationship between self-efficacy beliefs regarding the English and teaching skills of prospective English teachers (Unpublished doctoral dissertation), Y1ldizTeknik University, Institute of Social Sciences, Istanbul.

Çapa-Aydın, Y., \& Uzuntiryaki, E. (2009). Development and psychometric evaluation of the high school chemistry self-efficacy scale.Educational and Psychological Measurement, 69, 868-880. http://dx.doi.org/10.1177/0013164409332213

Carrier, J. S. (2009). Environmental education in the schoolyard: Learning styles and gender. The Journal of Environmental Education, 40(3), 3-12. http://dx.doi.org/10.3200/JOEE.40.3.2-12

Chen, C. S. (2002). Self-regulated learning strategies and achievement in an introduction to information system course. Information Technology, Learning, and Performance, 20(1), 11-25.

Dalgety, J., \&Coll, R. K. (2006). The influence of first year chemistry learning experiences on enrolment choices. Assessment and Evaluation in Higher Education, 31(3), 303-328. http://dx.doi.org/10.1007/s10763-005-1080-3

Dalgety, J., Coll, R. K., \& Jones, A. (2003). Development of chemistry attitudes and experiences questionnaire (CAEQ).Journal of Research in Science Teaching, 40(7), 649-668. http://dx.doi.org/10.1002/tea.10103

EkinciVural, D., \& Hamurcu, H. (2008). Preschool teacher candidates' self-efficacy beliefs regarding science teaching lesson and opinions about science. Elementary Education Online, 7(2), 456-467.

Fay, M. P., \& Proschan, M. A. (2010). Wilcoxon-Mann-Whitney or t-test? On assumptions for hypothesis tests and multiple interpretations of decision rules. Statistics Surveys, 4, 1-39. http://dx.doi.org/10.1214/09-SS051.

Freed, M. N., Hess, R. K., \& Ryan, J. M. (2002). The educator's desk reference (EDR): A sourcebook of educational information and research. Westport, CT: Praeger. 
Garcia, C. A. (2010). Tracking chemistry self-efficacy and achievement in a preparatory chemistry course (Unpublished doctoral dissertation), South Florida University, Tampa, Florida, USA.

Garcia, T. (1996). Self-regulation: An introduction. Learning and Individual Differences, 8(3), 161-163, http://dx.doi.org/10.1016/S1041-6080(96)90012-6

Gibson, S., \& Dembo, M. H. (1984). Teacher efficacy: A construct validation. Journal of Educational Psychology, 76(4), $569-582$.

Güngör, S. H., \& Eyceyurt, T. G. (2015). The Turkish adaptation of the "Chemistry Self-Efficacy Scale" for university students: A validity and reliability study. The Journal of Academic Social Science Studies (JASSS), 35, 199-211. http://dx.doi.org/10.9761/JASSS2898

Gwilliam, L. R., \& Betz, N. E. (2001). Validity of measures of math- and science-related self-efficacy for African Americans and European Americans. Journal of Career Assessment, 9(3), 261-281. http://dx.doi.org/10.1177/106907270100900304

Haşlaman, T., \& Aşkar, P. (2007). Investigating the relationship between self-regulated learning strategies and achievement in a programming course. Hacettepe University Journal Education, 32, 110-122.

Institute for Digital Research and Education (IDRE), What statistical analysis should I use? Statistical analyses using Stata, Retrieved December 11, 2015. http://www.ats.ucla.edu/stat/stata/whatstat/whatstat.htm.

İşler, I. (2008). Teachers' perceived efficacy beliefs and perceptions regarding the implementation of the 2004 primary mathematics curriculum (Unpublished master's thesis), Middle East Technical University, The Department of Elementary Science and Mathematics Education, Ankara.

Kadıŏlu, C., Uzuntiryaki, E., \& Çapa, A. Y. (2011).Development of self-regulatory strategies scale (SRSS). Education and Science, 36(160), 11-23.

Kalayc1, Ş. (2008), SPSS Applied Multivariate Statistical Techniques, Ankara: Asil Publishing.

Kan, A., \& Akbaş, A. (2006).Affective factors that influence chemistry achievement (attitude and self-efficacy) and the power of these factors to predict chemistry achievement-I. Journal of Turkish Science Education, 3, 76-85.

Karasar, N. (2005). Scientific Research Method. Ankara: Nobel Publishing.

Kerns, E.M. (1981). Chemistry self-efficacy and its relationship to the avoidance of chemistry-related majors and careers (Unpublished honors thesis), Ohio State University, Columbus.

Larose, S., Ratelle, C. F., Guay, F., Senécal, C., \& Harvey, M. (2006).Trajectories of science self-efficacy beliefs during the college transition and academic and vocational adjustment in science and technology programs. Educational Research and Evaluation, 12(4), 373-393.

Lau, S., \& Roeser, R. W. (2002).Cognitive abilities and motivational processes in high school students' situational engagement and achievement in science. Educational Assessment, 8(2), 139-162. http://dx.doi.org/10.1207/S15326977EA0802_04

Lent, R. W., Lopez, F. G., \& Bieschke, K. (1991). Mathematics self-efficacy: Sources and relation to science-based career choice. Journal of Counseling Psychology, 38(4), 424-430.

Lloyd, J. E. V., Walsh, J., \& Yailagh, M. S. (2005). Sex differences in performance attributions, self-efficacy, and achievement in mathematics: If I am so smart, why don't i know it?" Canadian Journal of Education, 28(3), 384-408.

Lodewyk, K. R., \&Winne, P. H. (2005).Relations among the structure of learning tasks, achievement, and changes in self-efficacy in secondary students. Journal of Educational Psychology, 97, 3-12.

Loong, T. E. (2012). Self-regulated learning strategies and pre-university math performance of international students in Malaysia. Journal of International Education Research, 8(3), 223-232.

Michaelides; M. P. (2008). Emerging themes from early research on self-efficacy beliefs in school mathematics. Electronic Journal of Research in Educational Psychology, 6(1), 219-234.

Neber, H., \& Schommer-Aikins, M. (2002). Self-regulated science learning with highly gifted students: The role of cognitive, motivational, epistemological, and environmental variables. High Ability Studies, 13(1), 59-74.

Nevgi, A. (2002). Measurement of learning strategies - Creating a self-rating tool for students of virtual university.In H. Niemi\& P. Ruohotie (Eds.), Theoretical understandings for learning in the virtual university (pp. 197-220). Hämeenlinna: Research Centre for Vocational Education and Training. 
Niemi, H., Nevgi, A., \& Virtanen, P. (2003).Towards self-regulation in web-based learning. Journal of Educational Media, 28, 49-71.

Ning, H. K., \& Downing, K. (2014). A latent profile analysis of university students' self-regulated learning strategies, Studies in Higher Education, 40(7), 1328-1346. http://dx.doi.org/10.1080/03075079.2014.880832

Olaussen, B. S., \& Bråten, I. (1999). Students' use of strategies for self-regulated learning: Cross-cultural perspectives, Scandinavian Journal of Educational Research, 43(4), 409-432. http://dx.doi.org/10.1080/0031383990430405.

Ongowo, R. O., \& Hungi, S. K. (2014). Motivational beliefs and self-regulation in biology learning: Influence of ethnicity, gender and grade level in Kenya. Creative Education, 5, 218-227.

Orhan, F. (2008). Self-regulation strategies used in a practicum course: A study of motivation and teaching self -efficacy. Hacettepe University Journal of Education, 35, 251-262.

Pajares, F. (1996). Self-efficacy beliefs in achievement settings. Review of Educational Research, 66, 543-578. http://dx.doi.org/10.3102/00346543066004543

Pajares, F. (2002).Gender and perceived self-efficacy in self-regulated learning.Theory into Practice, 41(2), 116.http://dx.doi.org/10.1207/s15430421tip4102_8

Palmer, D. (2006). Sources of self-efficacy in a science methods course for primary teacher education students. Research in Science Education, 36, 337-353.

Panadero, E., \& Romero, M. (2014).To rubric or not to rubric? The effects of self-assessment on self-regulation, performance and self-efficacy, assessment in education: Principles, Policy \& Practice, 21(2), 133-148.

Pintrich, P. (1995). Understanding self-regulated learning. New Directions for Teaching and Learning, 63, 3-12, http://dx.doi.org/10.1002/t1.37219956304

Pintrich, P. R., \& De Groot, E. (1990).Motivational and self-regulated learning components of classroom academic performance. Journal of Educational Psychology, 82(1), 33-40.

Purdie, N., Hattie, J., \& Douglas, G. (1996). Student conceptions of learning and their use of self-regulated learning strategies: a cross-cultural comparison. Journal of Educational Psychology, 88(1), 87-100.

Puustinen, M., \& Pulkkinen, L. (2001). Models of Self-regulated Learning: A review. Scandinavian Journal of Educational Research, 45(3), 269-286. http://dx.doi.org/10.1080/00313830120074206

Quimby, J. L., \& O'Brien, K. M. (2004). Predictors of student and career decision-making self efficacy among nontraditional college women. Career Development Quarterly, 52(4), 323-339. http://dx.doi.org/10.1002/j.2161-0045.2004.tb00949.x

Ritter, J. M., Boone, W. J., \& Rubba, P. A. (2001). Development of an instrument to assess prospective elementary teacher self-efficacy beliefs about equitable science teaching and learning (SEBEST). Journal of Science Teacher Education, 12(3), 175-198. http://dx.doi.org/10.1023/A:1016747713585

Schloemer, P., \& Brenan, K. (2006). From students to learners: Developing self-regulated learning. Journal of Education for Business, 82(2), 81-87. http://dx.doi.org/10.3200/JOEB.82.2.81-87

Schmitz, B., \& Wiese, B. S. (2006). New perspectives for the evaluation of training sessions in self-regulated learning: time-series analyses of diary data. Contemporary Educational Psychology, 31(1), 64-96. http://dx.doi.org/10.1016/j.cedpsych.2005.02.002

Schunk, D. H., \& Zimmerman B. J. (1998). Social origins of self-regulatory competence.Educational Psychologist, 32(4), 195-208.

Scott, A. B., \& Mallinckrodt, B. (2005). Parental emotional support, science self-efficacy, and choice of science major in undergraduate women. The Career Development Quarterly, 53(3), 263-273. http://dx.doi.org/10.1002/j.2161-0045.2005.tb00995.x

Şenler, B., \& Sungur-Vural, S. (2014). Prospective science teachers' use of self-regulation strategies. Procedia - Social and Behavioral Sciences, ERPA 2014, 152, 551-556.

Smist, J. M. (1993). General chemistry and self-efficacy. Paper presented at the National Meeting of the American Chemical Society, (August), Chicago, IL.

Stoeger, H., \& Ziegler, A. (2005). Evaluation of an elementary classroom self-regulated learning program for gifted math underachievers. International Education Journal, 6, 261-271.

Summers, D. M. (2009). An Examination of Factors Affecting Nontraditional Students' Chemistry Self-Efficacy 
(Unpublished master's thesis), Alaska Anchorage University, Anchorage, Alaska.

Tang, M., \& Neber, H. (2008). Motivation and self-regulated science learning in high achieving students: Differences related to nation, gender and grade level. High Ability Studies, 19, 103-116.

Tunde, O. (2014). Self-regulated learning strategies on academic performance of students in senior secondary school chemistry.US-China Education Review A. 4(11), 799-805.

Velayutham, S., Aldridge, J., \& Fraser, B. (2011). Development and validation of an instrument to measure students' motivation and self-regulation in science learning. International Journal of Science Education, 33(15), 2159-2179. http://dx.doi.org/10.1080/09500693.2010.541529

Virtanen, P., \& Nevgi, A. (2010). Disciplinary and gender differences among higher education students in self-regulated learning strategies, Educational Psychology: An International Journal of Experimental Educational Psychology, 30(3), 323-347.

Webster, E. A., \& Hadwin, A. F. (2014). Emotions and emotion regulation in undergraduate studying: examining students' reports from a self-regulated learning perspective, Educational Psychology: An International Journal of Experimental Educational Psychology. http://dx.doi.org/10.1080/01443410.2014.895292

Winne, P. (1997). Experimenting to bootstrap self-regulated learning.Journal of Educational Psychology, 89(3), 410-379.

Winne, P.H., \&Hadwin, A.F. (2008).The weave of motivation and self-regulated learning. D. H. Schunk\& B. J. Zimmerman (Eds.), Motivation and self-regulated learning: Theory, research, and applications (pp. 297-314). New York, NY: Lawrence Erlbaum.

Winter, J. C., \& Dodou, D., (2010). Five-point Likert items: t test versus Mann-Whitney-Wilcoxon. Practical Assessment, Research \& Evaluation, 15(11), 1-12.

https://www.researchgate.net/post/Chi-Square-Mann-Whitney-t-test [Accessed Dec 15, 2015]

Wolters, C. A., \&Pintrich, P. R. (1998). Contextual differences in student motivation and self-regulated learning in mathematics, english, and social studies classrooms. Instructional Science, 26, 27-47. http://dx.doi.org/10.1023/A:1003035929216

Yip, M. C. W. (2007), Differences between high and low academic-achieving university students in learning and study strategies: a Hong Kong study. Educational Psychology, 27(1), 597-606. http://dx.doi.org/10.1080/01443410701309126

Yükseltürk, E., \& Bulut, S. (2009). Gender differences in self-regulated online learning environment. Educational Technology \& Society, 12 (3), 12-22.

Zeidner, M., Boekaerts, M., \&Pintrich, P. R. (2000). Self-regulation: directions and challenges for future research. In M. Boekaerts, P.R. Pintrich\&M. Zeidner (eds), Handbook of Self-regulation. San Diego, CA: Academic Press.

Zeldin, A. L., \& Pajares, F. (2000). Against the odds: Self-efficacy beliefs of women in mathematical, scientific, and technological careers. American Educational Research Journal, 37, 215-246. http://dx.doi.org/10.3102/00028312037001215

Zimmerman, B. J. (1990). Self-regulated learning and academic achievement: An overview. Educational Psychologist, 25(1), 3-17.

Zimmerman, B. J. (2000). Attaining self-regulation: A social cognitive perspective. M. Boekaerts, P. Pintrich, \& M. Ziedner (Eds.), Handbook of self-regulation (pp. 13-39). Orlando, FL: Academic Press.

Zimmerman, B. J. (2008). Investigating self-regulation and motivation: Historical background, methodological developments, and future prospects. American Educational Research Journal, 45(1), 166-183.

Zimmerman, B. J., \& Martinez-Pons, M. (1990). Student differences in self-regulated learning: relating grade, sex, and giftedness to self-efficacy and strategy use. Journal of Educational Psychology, 82(1), 51-59. http://dx.doi.org/10.1037/0022-0663.82.1.51

Zimmerman, B. J., \& Resemberg, R. (1997). Self-regulatory dimensions of academic learning and motivation. In G.D. Phye (Ed.), Handbook of academic learning, construction of knowledge (pp. 105-125). San Diego, C.A.: Academic Press.

Zimmerman, B. J., \&Schunk, D. H. (Eds) (1989).Self-regulated learning and academic achievement: Theory, research, and practice. New York: Springer-Verla.

Zimmerman, B. J., Bandura, A., \& Martinez-Pons, M. (1992). Self-motivation for academic attainment: The role of 
self-efficacy beliefs and personal goal setting. American Educational Research Journal, 29(3), 663-676. http://dx.doi.org/10.3102/00028312029003663

Zusho A., Pintrich P. R., \& Coppalo, B. (2003). Skill and will: the role of motivation and cognition in the learning of college chemistry. International journal of Science Education, 25(9), 1081-1094.

Zusho, A., \& Edwards, K. (2011).Self-regulation and achievement goals in the college classroom. New Directions for Teaching and Learning, 126, 21-31. http://dx.doi.org/10.1002/tl.441

\section{$(\mathrm{Cc}) \mathrm{BY}$}

This work is licensed under a Creative Commons Attribution 3.0 License. 